\title{
Tracing a key player in the regulation of plant architecture: the columnar growth habit of apple trees (Malus $\times$ domestica)
}

\author{
Romina Petersen · Clemens Krost
}

Received: 18 December 2012/ Accepted: 10 May 2013/Published online: 22 May 2013

(C) Springer-Verlag Berlin Heidelberg 2013

\begin{abstract}
Plant architecture is regulated by a complex interplay of some key players (often transcription factors), phytohormones and other signaling molecules such as microRNAs. The columnar growth habit of apple trees is a unique form of plant architecture characterized by thick and upright stems showing a compaction of internodes and carrying short fruit spurs instead of lateral branches. The molecular basis for columnar growth is a single dominant allele of the gene Columnar, whose identity, function and gene product are unknown. As a result of marker analyses, this gene has recently been fine-mapped to chromosome 10 at 18.51-19.09 $\mathrm{Mb}$ [according to the annotation of the apple genome by Velasco (2010)], a region containing a cluster of quantitative trait loci associated with plant architecture, but no homologs to the well-known key regulators of plant architecture. Columnar apple trees have a higher auxin/ cytokinin ratio and lower levels of gibberellins and abscisic acid than normal apple trees. Transcriptome analyses corroborate these results and additionally show differences in cell membrane and cell wall function. It can be expected that within the next year or two, an integration of these different research methodologies will reveal the identity of the Columnar gene. Besides enabling breeders to efficiently create new apple (and maybe related pear, peach, cherry, etc.) cultivars which combine desirable characteristics of commercial cultivars with the advantageous columnar
\end{abstract}

\footnotetext{
R. Petersen $(\bowtie) \cdot$ C. Krost

Department of Molecular Genetics,

Johannes Gutenberg-University of Mainz,

Johann-Joachim-Becher-Weg 32,

55128 Mainz, Germany

e-mail: peterser@uni-mainz.de

C. Krost

e-mail: clemenskrost@gmx.de
}

growth habit using gene technology, this will also provide new insights into an elevated level of plant growth regulation.

Keywords Apple - Columnar - Mapping - Quantitative trait loci $\cdot$ Phytohormones $\cdot$ Transcriptome analysis

$\begin{array}{ll}\text { Abbreviations } & \\ \text { A14 } & \text { A14-190-93 } \\ \text { ABA } & \text { Abscisic acid } \\ \text { AFLP } & \text { Amplified fragment length polymorphism } \\ \text { BA } & \text { 6-Benzyladenine } \\ \text { BAC } & \text { Bacterial artificial chromosome } \\ \text { BLAST } & \text { Basic local alignment search tool } \\ \text { BR } & \text { Brassinosteroid } \\ \text { CEN } & \text { Centroradialis } \\ \text { CK } & \text { Cytokinin } \\ \text { CO } & \text { Constans } \\ \text { Co } & \text { Columnar } \\ \text { FT } & \text { Flowering locus T } \\ \text { GA } & \text { Gibberellin } \\ \text { GC-MS-SIM } & \text { Gas chromatography-mass spectrometry- } \\ & \text { selected ion monitoring } \\ \text { GRAS } & \text { Gibberellic-acid insensitive-repressor of } \\ & \text { gibberellic-acid insensitive and scarecrow } \\ \text { IAA } & \text { Indole-3-acetic acid } \\ \text { KNOX } & \text { Knotted-1-like homeobox } \\ \text { LG } & \text { Linkage group } \\ \text { Mb } & \text { Megabases } \\ \text { MDP } & \text { Malus } x \text { domestica protein } \\ \text { miRNA } & \text { MicroRNA } \\ \text { P28 } & \text { Procats 28 } \\ \text { QTL } & \text { Quantitative trait loci } \\ \text { RAPD } & \text { Random amplification of polymorphic } \\ & \text { DNA } \\ & \end{array}$


SCAR

SL

SNP

SSR

TFL
Sequence characterized amplified region

Strigolactone

Single nucleotide polymorphism

Simple sequence repeat

Terminal flower

\section{Introduction}

Genetic control of plant architecture in herbaceous plants

The architecture of a plant defines the spatial arrangement of its individual (aerial) organs. With reference to the biological dogma of form and function being intrinsically tied to each other, studying plant architecture is crucial for the comprehension of plant function. Furthermore, controlling plant architecture has always been an important aim in plant breeding, as manipulating plants to grow to a smaller height and produce shorter branches, while at the same time maximizing yield, bears great economic advantages. This has been proven by the introduction of lodging-resistant semi-dwarf wheat and rice mutants that led to the Green Revolution in the 1960s (Peng et al. 1999) and by the adoption of dwarfing rootstocks in fruit tree breeding in the 1920s (Fideghelli et al. 2003).

Even though plant architecture is influenced by environmental factors such as light penetration, temperature, humidity and soil conditions including nutrient availability, the intrinsic body plan of the plant is genetically determined. During the past few years, significant progress has been made in the disclosure of genes that play a pivotal role in establishing the shape of the plant, mostly by examining herbaceous plants showing an aberrant architecture due to a mutation. This has been extensively reviewed elsewhere (Reinhardt and Kuhlemeier 2001; Wang and Li 2008), so only a few key players and basic concepts which can be applied to most plant species are presented here (Fig. 1). For clarity, Arabidopsis nomenclature is used for genes and proteins unless indicated otherwise.

In the shoot apical meristem, a feedback loop between wuschel and clavata controls the balance between stem cell maintenance and organogenesis: wuschel (Laux et al. 1996; Mayer et al. 1998) maintains undifferentiated cells within the central zone and activates clavata 3 (Clark et al. 1995), whose gene product in turn together with Clavata 1 and Clavata 2 (Clark et al. 1993) restricts wuschel expression to a defined region, thus enabling cells in the peripheral zone to undergo differentiation (Brand et al. 2000; Schoof et al. 2000). The products of the knotted-1-like homeobox (KNOX) genes, with shoot meristemless as their best known member, are also responsible for stem cell maintenance
(Long et al. 1996; Hay and Tsiantis 2010). Furthermore, KNOX proteins define boundaries of newly formed organs via interactions with cup-shaped cotyledon proteins (Aida et al. 1999).

When lateral organ primordia are initiated, they are arranged in distinct phyllotactic patterns. These patterns are mainly controlled by auxin levels, as the primordia are induced by a local auxin maximum (Reinhardt et al. 2000; Benková et al. 2003). Therefore, genes regulating phyllotaxis are either genes establishing the organization of the shoot apical meristem or genes involved in auxin transport and signaling like pin-formed 1 (Reinhardt and Kuhlemeier 2001). Only mutants of terminal ear 1 (Veit et al. 1998) in maize and of perianthia (Running and Meyerowitz 1996) in Arabidopsis show alterations in phyllotactic patterns without also showing changes in the apical meristem. In the leaf primordia, phan, phabulosa and phavoluta establish the adaxial cell fate (McConnell et al. 2001), while yabby and kanadi promote abaxial cell fates (Siegfried et al. 1999; Kerstetter et al. 2001). Once the leaf has been formed, its shape is controlled by angustifolia in the lateral direction and rotundifolia in the longitudinal direction (Tsuge et al. 1996; Tsukaya 2005); lanceolate as well as KNOX induce the formation of compound leaves (Mathan and Jenkins 1962; Hareven et al. 1996).

In the axils of the leaves, axillary meristems either develop from cells of the shoot apical meristem that have maintained their stem cell identity (Garrison 1955; Sussex 1955) or from differentiated cells that undergo dedifferentiation (Snow and Snow 1942). The initiation of axillary meristems is regulated by revoluta (Otsuga et al. 2001), lateral suppressor (Greb et al. 2003) and branched 1 (Aguilar-Martínez et al. 2007). For the maintenance of stem cell identity, shoot meristemless is induced by CupShaped Cotyledon 1 (Hibara et al. 2003), indicating similar regulatory loops in axillary meristems as in the apical meristem. Axillary meristems generate axillary buds, which can remain dormant or grow out to form lateral shoots (Shimizu-sato and Mori 2001). This is regulated by apical dominance, a concept described below. In addition, the angle at which lateral shoots grow out largely contributes to overall plant architecture. The control of the crotch angle has not yet been thoroughly researched, but recently lazy 1 and tac 1 have been shown to play important roles as a negative and a positive regulator, respectively, of tiller angle in maize ( $\mathrm{Li}$ et al. 2007; Yu et al. 2007).

The final important decision in a plant's life is the phase change from vegetative to reproductive growth. For many herbaceous plants, producing a flower and subsequently fruit represents the end of their life cycle. This developmental switch therefore has to be precisely controlled; revoluta, knotted-1-like 1 and erecta are essential players 
Fig. 1 Major aspects of plant architecture regulation. The shape of a dicotyledonous plant is regulated by some key proteins (left-hand side) and phytohormones (right-hand side) that show promotive headed arrow) effects on shoot apical meristem activity (top), floral meristem activity, inflorescence branching and vegetative branching (bottom) as well as on elongation growth (double-headed vertical arrow) headed horizontal arrow). For detailed explanations see text. brassinosteroid, $C K$ cytokinin, $C U C$ cup-shaped cotyledon, $G A$ gibberellin, IAA indole-3-acetic acid, KNOX knotted-1-like homeobox, LAS lateral suppressor, Phab phabulosa, Phav phavoluta, $S L$ strigolactone, STM shoot meristemless (arrows) or inhibitory (barand secondary growth (double$A B A$ abscisic acid, $B R$

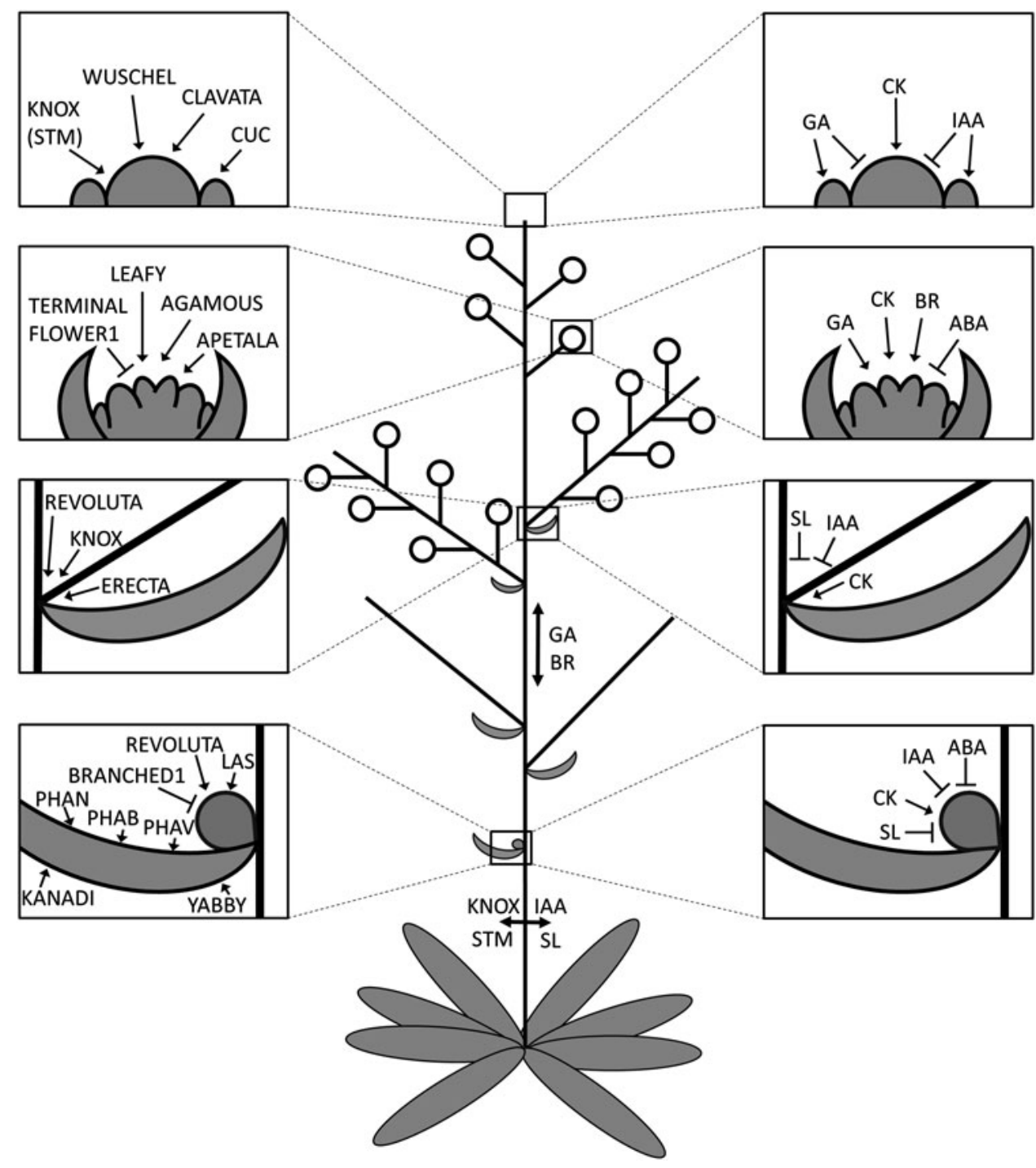

in the regulation of inflorescence architecture (Douglas et al. 2002). In Arabidopsis, five genetically defined but cross talking pathways have been identified in the control of flowering (recently reviewed in Srikanth and Schmid 2011): the vernalization pathway, the photoperiod pathway, the gibberellin pathway, the autonomous pathway and the aging pathway. Focusing on a simplified view of the photoperiod and autonomous pathways, under long days constans $(\mathrm{CO})$ mRNA is stabilized at the end of the day (with the help of phytochrome A and due to the influence of gigantea) and activates the transcription of flowering locus $T(F T)$ and twin sister of FT (Kardailsky et al. 1999; Kobayashi et al. 1999; Samach et al. 2000; Suarez-Lopez et al. 2001; Valverde et al. 2004). FT moves through the phloem into the meristem and, together with flowering locus D, activates apetala 1, fruitful and suppressor of overexpression of constans (Abe et al. 2005; Wigge et al. 2005; Yoo et al. 2005). Floral meristem identity genes like apetala (Irish and Sussex 1990) and leafy (Weigel et al. 1992) transform indeterminate axillary meristems into determinate floral meristems. Leafy directly activates apetala 1 redundantly with FT and also induces the transcription of the homeotic genes agamous and apetala 3 (Busch et al. 1999; Lamb et al. 2002). The antagonist of leafy is terminal flower 1 (TFL1), which favors indeterminate vegetative growth (Shannon and Meeks-Wagner 1991).

While the individual parts of the plant are being built, intercalary meristems mediate elongation growth as well as secondary growth of the main axis and lateral organs. Elongation growth of the main axis occurs via cell divisions and subsequent internode elongation. Internode elongation is mainly hormonally controlled (see below), but regulators of cell division or cell wall remodeling and polyamine signals also influence cell elongation in the stem (Hanzawa et al. 2000; Zhou et al. 2006; Asano et al. 2010; 
Todaka et al. 2012). The increase in stem diameter is caused by the formation of secondary xylem and secondary phloem by the vascular cambium. This process seems to be regulated in essentially the same way as primary growth because it involves wuschel-related homeobox and clavata 3/ESR-related factors (Schrader et al. 2004; Hirakawa et al. 2010) and requires shoot meristemless and KNOX genes for the maintenance of stem cell identity (Groover et al. 2006; Du et al. 2009; Zhang et al. 2011).

Phytohormones regulating plant architecture in herbaceous plants

For a plant as a sessile organism, it is crucial to establish a stable architecture while at the same time maintaining the possibility to modify the spatial arrangement of its individual parts to adapt to environmental changes. Thus, plant architecture is dynamic and extensive signal integration and crosstalk constantly take place for its precise control. Most long-distance signaling within the plant is accomplished via the highly interconnected network of the different phytohormones, and the regulation of architecture is no exception to this rule (Fig. 1).

Auxins, the most important representative being indole3-acetic acid (IAA), are involved in nearly all aspects of plant growth and development (reviewed in Overvoorde et al. 2010; Müller and Leyser 2011; Durbak et al. 2012). As mentioned above, auxin levels determine the sites of organ primordia formation (Reinhardt et al. 2000). They are also the predominant mediator of apical dominance, which is defined as the control exerted by the apical portions of the main shoot over the outgrowth of lateral buds (Cline 1991). The high auxin content in the shoot apex regulates ramification because it usually suppresses the outgrowth of lateral shoots so that the latter usually only take over in case the leader is damaged and its influence ceases (Thimann and Skoog 1933; Cline 1991), although outgrowth can also occur under "vigorous" growth conditions or on vigorous rootstocks. The regulation of apical dominance has been extensively discussed elsewhere (Leyser 2005; Rameau 2010; Domagalska and Leyser 2011) and will thus not be discussed in detail. Clearly, the polar basipetal IAA transport within the dominant stem, mediated via the asymmetric distribution of auxin influx carriers of the Auxin Resistant 1/Like Auxin Resistant family (Swarup et al. 2008; Péret et al. 2012; Swarup and Péret 2012) and auxin efflux carriers of the Pin-formed family (Gälweiler et al. 1998; Palme and Gälweiler 1999; Křeček et al. 2009), plays a central role in the establishment of apical dominance (Friml and Palme 2002). The polar auxin transport in the main shoot either hinders the lateral buds from establishing their own auxin flux which then prevents their outgrowth ( $\mathrm{Li}$ and Bangerth 1999), or it regulates the levels of a second, upwardly moving messenger of bud sprouting (Snow 1929; Sachs and Thimann 1967). Cytokinins (CKs) and strigolactones (SLs) are the most likely candidates for this second messenger: direct CK application to the lateral bud promotes its outgrowth (Cline 1991), whereas SLs act as a branching inhibitor (Gomez-Roldan et al. 2008; Umehara et al. 2008). Furthermore, CK and SL levels have been shown to be regulated by IAA (Nordström et al. 2004; Johnson et al. 2006; Brewer et al. 2009). In turn, CK induces IAA biosynthesis (Jones et al. 2010), and genes involved in the biosynthesis and/or signaling of SLs act as negative regulators of polar auxin transport (Bennett et al. 2006). As a central component of plant development, auxin crosstalks with nearly all other phytohormones (reviewed in Chandler 2009). The interplay between auxin and SLs not only determines sprouting but also stimulates secondary growth (Agusti et al. 2011).

Besides auxin, CKs are essential for plant growth, since they generally are stimulators of cytokinesis (Hartig and Beck 2006). As such, they maintain the activity of the vegetative and floral shoot apical meristem (Riou-Khamlichi et al. 1999), regulate cambial activity (MatsumotoKitano et al. 2008; Nieminen et al. 2008) and antagonize the inhibitory effect of auxin on the outgrowth of lateral buds. Contrary to their promotive role for growth of the aerial parts of the plant, they negatively regulate root apical meristem activity and lateral root formation (Werner et al. 2003).

In addition to cytokinesis, cell elongation is essential for growth to take place. Elongation growth is mainly mediated via gibberellins (GAs) and brassinosteroids (BRs) (reviewed in Phinney 1985; Müssig 2005), which stimulate internode elongation (Yamamuro et al. 2000; Dayan et al. 2012; Li et al. 2012). Ethylene signaling has been shown to influence internode elongation in rice adapted to deep water conditions (Hattori et al. 2009; Qi et al. 2011), and IAA contributes to elongation growth in pea (McKay et al. 1994). Low GA levels in the shoot apical meristem together with the high CK/IAA ratio favor the maintenance of stem cells, whereas high GA and low CK/IAA ratio induce the formation of lateral organs (Shani et al. 2006). GAs and BRs also promote flowering (Langridge 1957; Wilson et al. 1992; Domagalska et al. 2010). This effect is antagonized by abscisic acid (ABA), which generally has an inhibitory role on plant growth (Milborrow 1967).

The remaining three groups of phytohormones are ethylene, jasmonates and salicylic acid; however, they only play a minor role in the regulation of plant shape, except under stress conditions (Xu et al. 1994; Zhang and Turner 2008; Sehr et al. 2010). In contrast, the past few years have shown that other molecules like microRNAs (miRNAs) highly influence plant architecture (Chen et al. 2010; Jiao 
et al. 2010). It is often not yet clear at which points and in which way phytohormone or miRNA pathways and the key genes for the regulation of plant architecture converge. The input from several signaling pathways is probably integrated to fine-tune a few final developmental switches.

\section{Approaching tree architecture}

To date, our understanding of plant architecture establishment as described above is mostly based on results obtained from the herbaceous model organism Arabidopsis thaliana and the economically important cereals such as rice or maize. In contrast, research on tree architecture has long been mainly descriptive (e.g., Ceulemans et al. 1990; Costes et al. 2006). However, during the past few years, the genus Populus (including poplars and aspen) has emerged as a model for the study of tree architecture and physiology, supported by the sequencing of its genome, which was the first tree genome to be completed (Tuskan et al. 2006; Wullschleger et al. 2013). As the number of available genome sequences of perennial plants continues to increase (Jaillon et al. 2007; Velasco et al. 2010; Shulaev et al. 2011; Verde et al. 2013), the unraveling of the regulation of tree architecture has been greatly accelerated. Most of the genes and mechanisms described in the previous sections have homologs and equivalents in woody plants. Sometimes two or more orthologs to each Arabidopsis gene can be found due to gene duplication, and these paralogous genes might show different expression patterns and fulfill slightly different roles. For instance, Populus has several wuschel and shoot meristemless orthologs, which in addition to regulating stem cell maintenance in the SAM also play a similar role in the vascular cambium (Schrader et al. 2004; Groover 2005; Groover et al. 2006; Bao et al. 2009). With regard to the regulation of flowering, Populus has two orthologs of FT (see below), TFL 1 (Mohamed et al. 2010) and agamous (Brunner et al. 2000), respectively, and in apple, two leafy orthologs with different expression patterns and thus possibly different functions can be detected (Wada et al. 2002). Functional differences of certain genes in Arabidopsis and trees have been reported, especially in the case of heterologous transformation (Gocal et al. 2001; Flachowsky et al. 2010).

Trees and herbaceous plants also share all key concepts of phytohormone regulation. In trees, IAA is involved in the control of apical dominance and apical control, acting in combination with CKs (Wilson 2000; Cline and Dong-Il 2002). For perennial plants, "apical dominance" only refers to the decision between outgrowth or bud formation of the current year's axillary meristems (yielding sylleptic branches), whereas the term "apical control" is used to describe the influence of apical parts of the tree on the growth of lateral shoots and of previously dormant buds in subsequent years (yielding sylleptic and proleptic branches) (Brown et al. 1967; Cline 1997). Apical dominance and apical control are dynamic in time and can be modified in response to environmental effects. IAA also regulates secondary growth, which is more pronounced in trees because their longevity combined with the indeterminate growth of plants leads to a higher average plant size and biomass compared with annual plants, necessitating the reinforcement of the plant body. In this context, the formation of a radial auxin gradient with a peak in the cambium and the adjacent first few layers of xylem cells and its synergistic action with GA in wood formation have been intensively researched (Uggla et al. 1996, 1998; Eriksson et al. 2000; Israelsson et al. 2005; Björklund et al. 2007; Nilsson et al. 2008; Mauriat and Moritz 2009; Han et al. 2011; Chen et al. 2013). Furthermore, GAs affect elongation growth (Han et al. 2011; Elias et al. 2012) as well as flowering of perennial plants (Zawaski et al. 2011; Randoux et al. 2012). They also control seed dormancy together with ABA (reviewed in Graeber et al. 2012). ABA regulates responses to abiotic stresses, especially drought (Li et al. 2004; Popko et al. 2010; Ji et al. 2013).

To gain an advantage in the competition for light and nutrients during their first few years of life and to build up constructional and photosynthetically active organs before the formation of reproductive structures, most trees undergo a juvenile phase in which they cannot be induced to flower (Hackett 1985). This phase can last several years; for instance, poplar and apple flower for the first time after 7-10 and 4-8 years, respectively (Hackett et al. 1985; Hsu et al. 2006). The transition from the juvenile to the adult phase is regulated by the CO/FT regulatory module, similar to the photoperiod pathway of the transition from the vegetative to the reproductive phase in Arabidopsis described above. FT transcription gradually increases during the juvenile phase (Böhlenius et al. 2006), and Populus plants overexpressing the FT homologs FTI or $F T 2$ as well as plum plants transformed with poplar FT1 show an early flowering phenotype (Böhlenius et al. 2006; Hsu et al. 2006, 2011; Srinivasan et al. 2012). Downregulation of the Populus TFL homologs Populus Centroradialis 1 (PopCEN1) and Populus Centroradialis 2 (PopCEN2) leads to precocious maturity (Mohamed et al. 2010). In addition, miR 156 and miR 172 contribute to the control of vegetative phase change (reviewed in Huijser and Schmid 2011).

Perennial plants of temperate and boreal regions need to adapt to seasonality and develop a strategy to survive the winter period with its unfavorable growth conditions. For this purpose, most trees initiate bud set in late summer and then undergo a period of bud dormancy (for a recent comprehensive review, see Cooke et al. 2012). From a physiological point of view, dormancy has been divided 
into three phases: paradormancy, caused by inhibitors in leaves and terminal buds, ecodormancy, due to unfavorable environmental conditions, and endodormancy, caused by inhibitors within the bud itself (Lang 1987; Lang et al. 1987). Later it has been redefined independently of external and internal stimuli as the inability of a meristem to resume growth under favorable conditions (Rohde and Bhalerao 2007). This can be applied to the apical meristem as well as to the axillary meristems and the cambium. While the cambium is sheltered by the bark, the SAM and the axillary meristems are enclosed in buds, providing protection in the winter period. Buds are highly important for both vegetative and reproductive growth of trees since they are in fact undeveloped shoots. While most trees produce vegetative buds that develop into vegetative shoots and flower buds that develop into flowers, some species such as apple and pear produce vegetative and mixed buds, the latter of which can develop into leafy shoots as well as flowers (Mimida et al. 2009). In these species, a mixed unit ("bourse") containing vegetative and floral organs can occur. A bourse can subsequently form a sylleptic axillary shoot ("bourse shoot") that can finally develop into a short or long shoot (Costes and Guédon 2002). The decision whether a bud turns into a flower/fruit or shoot is controlled by various factors such as cultivar, rootstock, shoot growth and phytohormones (Hoad 1984; Buban 1996; Koutinas et al. 2010).

Cessation of apical elongation growth and bud set are the first steps to winter dormancy. Most plants induce these processes in response to shortening of day length (Heide 1974; Junttila 2007), whereas species of the Rosaceae family such as apple react to lower temperatures (Heide and Prestrud 2005; Heide 2008). Species with a strictly determinate growth pattern, in which the terminal bud contains all preformed primordia and internodes for the subsequent growth period, show autonomous control of bud set and growth cessation with almost no influence of environmental changes (Junttila 1976). Dormancy release occurs in answer to the fulfillment of a chilling requirement and/or a longer photoperiod (Murray et al. 1989; Heide 1993; Junttila and Hänninen 2012). The longer and the colder is the chilling period, the lower are the time and temperature sum to bud burst (Junttila and Hänninen 2012). The master switch in the regulation of onset as well as release of seasonal arrest is again the CO/FT module sensing day length in relation to the circadian clock (for a recent review on the circadian clock, see Farrè et al. 2012). Additionally, the circadian clock might be able to sense temperature in Arabidopsis (Edwards et al. 2006; Gould et al. 2006). In Populus, FT2 controls growth cessation, bud set and dormancy induction, and FTl is expressed during the chilling period to induce the transition from the vegetative to the reproductive phase (Böhlenius et al. 2006,
Hsu et al. 2006, 2011; Rinne et al. 2011). Furthermore, overexpression of CEN/TFL1 in Populus causes delayed bud break and altered chilling requirements (Mohamed et al. 2010). Aintegumenta-like genes (regulators of cell division) and dormancy-induced MADS-box genes are downstream targets of CO/FT (Karlberg et al. 2011; Yamane et al. 2011). Additional downstream effects related to dormancy induction are the upregulation of genes associated with cold hardiness and drought, defense, carbohydrate synthesis and transport, cell wall biosynthesis or modification as well as RNA metabolism and chromatin modification/remodeling (Ruttink et al. 2007; Park et al. 2008; Ko et al. 2011). In contrast, the transition from dormancy to active growth is characterized by the induction of flowering pathways, RNA metabolism and protein biosynthesis and transport (Larisch et al. 2012). It has been found that SAM cells are symplastically isolated during the dormant period due to the formation of a callose block at the plasmodesmata (Rinne and van der Schoot 1998; Rinne et al. 2001; Rinne et al. 2011). However, it is not yet clear whether there is a causal relationship between the cellular isolation and the activity-dormancy cycle. Phytohormone levels are also altered by the circadian clock in response to dormancy. A short photoperiod causes downregulation of Gibberellic Acid 20 oxidase and correspondingly decreases GA levels, which induce growth cessation (Eriksson and Moritz 2002). ABA has a central role in seed dormancy and has long been thought to mediate bud dormancy as well (Knox and Wareing 1984). Its precise role in bud dormancy is still unclear, but it seems to be involved in the control of bud development and maturation, as $A B A$ insensitive 3 overexpressing plants develop defective buds, but normal dormancy (Ruttink et al. 2007). Ethylene might crosstalk with ABA to regulate bud dormancy induction and bud morphology (Ruttink et al. 2007). The decreased cell division capacity of the cambium during winter dormancy has been shown to be accompanied by decreased auxin sensitivity (Schrader et al. 2004; Baba et al. 2011). Furthermore, there might be epigenetical (Santamaria et al. 2009, 2011), miRNA (Wang et al. 2011) and metabolism (sugars, energy status, redox state and reactive oxygen species) aspects of the regulation of winter dormancy (Halaly et al. 2008; Ophir et al. 2009), but research on these topics is still underway.

It would be of great value to gain an even deeper insight into the control of plant architecture in trees, with the possibility to transfer the new knowledge to other plant species. The columnar growth phenotype of apple is a natural mutation with the potential to reveal a key player in the regulation of tree architecture since it is dominantly inherited. As columnar apple trees show a thicker main stem with shorter internodes than apple trees with a standard growth habit and since many short fruit spurs emanate 


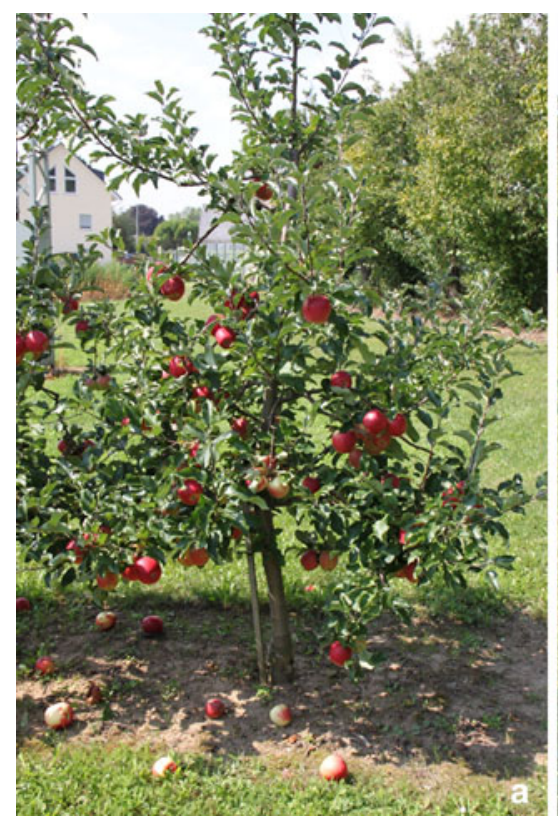

Fig. 2 Comparison of the plant architecture of standard and columnar type apple trees. a Apple trees with standard growth habit (variety A14) have long lateral branches with a wide crotch angle and usually require staking. b By contrast, columnar apple trees (variety Goldcats) do not require wood stakes and show compact growth.

from the main stem of columnar apple trees at a narrower crotch angle than the long lateral shoots of standard apple trees (Fig. 2), its causative gene, Columnar ( $\mathrm{Co}$ ), seems to influence nearly all aspects of plant architecture. At the same time, it could equip apple breeders with an important tool for the generation of new cultivars with high economic importance. Therefore, this review will briefly address the history and development of the columnar growth habit and then focus on the different approaches that are currently being taken to identify $\mathrm{Co}$ and its function.

\section{History and development of the columnar growth habit}

In the 1960s, researchers at East Malling in Kent were trying to revolutionize fruit tree breeding by the induction of mutations in apple (Malus $\times$ domestica) and the subsequent examination of the resulting phenotypes, focusing on spur type trees. The spur type growth habit was first recorded in the 1920s and is characterized by the formation of numerous short fruit spurs instead of large side branches (Quinlan and Tobutt 1990). However, the spur type is a fruiting type rather than a growth habit (Fideghelli et al. 2003), and an extreme of a continuous variation rather than a distinct heritable trait (Looney and Lane 1984), so in targeted breeding experiments, almost none of the spur type varieties transferred the desired phenotype to their progeny to a significant extent (Lapins 1969). c The pillar-like growth of columnar trees (here variety A73-75-97K) is due to short fruit spurs and few longer lateral branches emanating at a narrow crotch angle and growing almost parallel to the stem. Pictures were taken at the Geisenheim University in early fall 2011 (a, b) and early spring 2013 (c)

Being trained to watch out specifically for spur type mutants, in 1961 grower Anthony Wijcik spotted a very compact and spurry limb sport atop a 50-year-old McIntosh tree at the Summerland Research Station, British Columbia, which arose as a result of a spontaneous somatoclonal mutation (Fisher 1969, 1995). Fruits from this sport reached maturity slightly later than that of the rest of the tree and had a less intensive color (Fisher 1995). Vegetative propagation of this sport, later called "McIntosh Wijcik" (commercially also known as "Starkspur Compact Mac"), and subsequent crosses with plants showing a normal growth habit demonstrated that almost $50 \%$ of its progeny showed the compact phenotype (Lapins 1969, 1974; Lapins and Watkins 1973), which was later referred to as columnar growth habit. A number of similar sports were found on top of other aging McIntosh trees, e.g., in the Bendig orchard at Summerland, but were not propagated (Looney and Lane 1984; Fisher 1995).

Using McIntosh Wijcik as a parent, thousands of crossings performed at East Malling yielded six more columnar apple varieties until 1991: Telamon (Waltz), Trajan (Polka), Tuscan (Bolero), Obelisk (Flamenco), Charlotte (Hercules) and Maypole (Tobutt 1994). These columnar apple trees of the first generation, known as the "Ballerina" trees due to their commercial names, were susceptible to scab, showed biennial bearing and their fruits were not competitive with those of the most popular commercial apple tree varieties such as Golden Delicious, 
Jonagold or Gala. Breeding approaches in Canada, the USA, China, Korea, Belgium, Lithuania, Russia, Great Britain, Germany and France have since produced columnar varieties like Arbat, Moonlight and Goldlane that bear fruits of higher quality than the original columnar varieties and are resistant to scab and other common diseases (Gelvonauskienë et al. 2006). However, breeding apples by conventional crossing is time-consuming and cost-intensive. Apples are highly heterozygous and self-incompatible (Hegedűs 2006; Newcomb et al. 2006), and many agronomically important traits are under polygenic control, which constrains the production of varieties with a specific combination of advantageous traits and increases the need for large progenies of crossings (Velasco et al. 2010). Furthermore, apples have a long juvenile period so that fruit quality can only be assessed after several years (Hackett 1985). Thus, the demand for methods of early detection of the growth phenotype and more efficient creation of new columnar apple cultivars has accelerated research of this interesting phenotype and its molecular cause.

\section{Phenotype characteristics of columnar type apple trees}

The compact growth of columnar type apple trees is based on their very thick and upright stems with almost no difference in diameter between the top and the bottom and short internodes, overall looking like a sturdy cordon (Fig. 2b) (Tobutt 1985, 1994). They produce short fruit spurs rather than long lateral branches (Fig. 2c). Rarely, the axillary buds do develop into long lateral shoots which then grow almost parallel to the stem at a very narrow crotch angle (Hemmat et al. 1997; Bai et al. 2012). The development of long side shoots is favored if the central leader is damaged, in which case two to three spurs near the top grow to about $50 \mathrm{~cm}$ of length (Tobutt 1985; Watanabe et al. 2006), which implicates that the lateral buds are under tight apical control. The new lateral shoots also show the columnar habit (Kenis and Keulemans 2007). If a number of lateral buds of 1-year-old branch sections are removed, then the reaction is that the more buds are removed the more likely the remaining ones are to grow out (Looney and Lane 1984), indicating a competition between individual spurs. Columnar trees have less sylleptic shoots and thus show higher apical dominance. They exhibit a lower level of acrotony and develop more proleptic shoots, which is in line with the hypothesis of the buds being under higher apical control than those of trees with standard growth habit (De Wit et al. 2000). Even though shoots of columnar apple trees grow longer during one vegetative season than shoots of normal trees (Watanabe et al. 2004), the central leader of McIntosh Wijcik grows to only about $55 \%$ the size of a standard McIntosh tree, and many of the other columnar and spur type trees are also smaller than normal trees (Lane and Looney 1982; Kelsey and Brown 1992). However, since this does not apply to all varieties, it is likely that columnar growth habit and dwarfing are two distinct traits that segregate independently (Eaton and Lapins 1970).

While the number of leaves per shoot is similar between normal and columnar apple trees (Lee and Looney 1977), the total leaf area is greater in columnar seedlings at 3 years of age (Zhang and Dai 2011), and the leaves themselves also show some differences. Leaves of columnar apple trees are dark green and very thick with long petioles and usually have a serrate or crenate margin (Lapins 1969; Tobutt 1988a, b, c, d; Sarwar et al. 1998). This is a characteristic of most other spur type growth habits as well (Liu and Eaton 1970). Microscopic examinations and detailed measurements have demonstrated that the leaves of columnar apple trees have a thicker palisade parenchyma as well as a greater dry weight and chlorophyll content (Gelvonauskis et al. 2006; Zhang and Dai 2011). This results in a higher net photosynthetic rate and transpiration rate of columnar compared with normal type apple trees (Zhang and Dai 2011).

The diameter of xylem vessels is bigger in shoots and roots of columnar than standard apples and the number of xylem vessels is also higher in roots of columnar trees (Zhang and Dai 2011). This together with the higher photosynthetic rate explains why these trees can produce high yields of fruit despite their compact growth, at least when they are grown on typical commercial rootstocks such as M9: they are able to efficiently transport water and minerals from the soil up through the stem and to produce a higher amount of sugar compounds. Regarding the number or width of phloem vessels, no differences were found (Zhang and Dai 2011).

Another characteristic of columnar apple varieties is that they often show frost and drought resistance, which might be due to their Canadian origin (Jacob 2010).

The columnar growth habit can be detected as soon as 2 weeks to 2 months after germination (Lee and Looney 1977; Meulenbroek et al. 1998). However, this early examination is often erroneous. A reliable verification of the phenotype is possible after about 2-3 years (Blazek 1992; Baldi et al. 2012). Even then, classification can be difficult because there is not always a clear distinction between different growth phenotypes and many intermediate types exist (Hemmat et al. 1997; Kim et al. 2003; Ikase and Dumbravs 2004; Moriya et al. 2009; Baldi et al. 2012). In addition to the age of the plants, the proportion of progeny with an intermediate growth habit resulting from a cross with a columnar parent seems to be dependent on the columnar variety used (Table 1) as well as on the growth 
Table 1 Results of crosses with columnar cultivars

\begin{tabular}{|c|c|c|c|c|c|c|}
\hline Cross (plant age) & $\begin{array}{l}\text { Total } \\
\text { plant } \\
\text { no. }\end{array}$ & $\begin{array}{l}\text { Co } \\
\text { plants }\end{array}$ & $\begin{array}{l}\text { Non- } \\
\text { co } \\
\text { plants }\end{array}$ & $\begin{array}{l}\text { Intermediate/ } \\
\text { non-classified } \\
\text { plants }\end{array}$ & $\begin{array}{l}\text { Percentage } \\
\text { of co } \\
\text { plants }\end{array}$ & References \\
\hline Golden Delicious $\times \underline{\text { McIntosh Wijcik (2) }}$ & 107 & 47 & 60 & 0 & 44 & Lapins (1969) \\
\hline $\begin{array}{l}\text { Wellington Bloomless } \times \underline{\text { McIntosh Wijcik }} \\
\underline{(2)}\end{array}$ & 140. & 46 & 94 & 0 & 33 & Tobutt (1994) \\
\hline Spencer Seedless $\times \underline{\text { SAxy }}^{\mathrm{a}}(2)$ & 604 & 297 & 307 & 0 & 49 & Tobutt (1994) \\
\hline McIntosh Wijcik $\times$ NY75441-67 (4) & 126 & 44 & 40 & 42 & 35 & Hemmat et al. (1997) \\
\hline Telamon $\times$ Braeburn $(2)$ & 59 & 21 & 38 & 0 & 36 & De Wit et al. (2000) \\
\hline$\underline{\text { Telamon }} \times$ Sunrise $(2)$ & 69 & 23 & 46 & 0 & 33 & De Wit et al. (2000) \\
\hline$\underline{\text { Telamon }} \times 110(2)$ & 82 & 37 & 39 & 0 & 42 & De Wit et al. (2000) \\
\hline Fuji $\times \underline{\text { Tuscan }}(3)$ & 227 & 69 & 41 & 117 & 30 & Kim et al. (2003) \\
\hline Arbat $\times$ Forele $(7)$ & 66 & 42 & 21 & 3 & 64 & Ikase and Dumbravs (2004) \\
\hline$\underline{\text { KV-11 }} \times$ Melba $(7)$ & 52 & 27 & 8 & 17 & 52 & Ikase and Dumbravs (2004) \\
\hline Telamon $\times$ Braeburn $^{\mathrm{b}}(2)$ & 247 & 108 & 134 & 5 & 44 & Kenis and Keulemans (2007) \\
\hline Fiesta $\times \underline{\text { Totem }}$ & 85 & 44 & 37 & 4 & 52 & $\begin{array}{l}\text { Férnandez-Férnandez et al. } \\
\text { (2008) }\end{array}$ \\
\hline Fuji $\times \underline{5-12786}(2)$ & 68 & 30 & 38 & 0 & 44 & Moriya et al. (2009) \\
\hline Fuji × $\underline{\text { NYCO7-G }}(9)$ & 271 & 156 & 104 & 11 & 58 & Bai et al. (2012) \\
\hline$\underline{\text { Telamon }} \times$ Braeburn $^{\mathrm{b}, \mathrm{c}}(5)$ & 222 & 105 & 113 & 4 & 47 & Bai et al. (2012) \\
\hline $6-837 \times \underline{5-8246}(2)$ & 100 & 46 & 54 & 0 & 46 & Moriya et al. (2012) \\
\hline Golden Delicious $\times \underline{\text { McIntosh Wijcik }}{ }^{\mathrm{b}}(6)$ & 101 & 40 & 61 & 0 & 40 & Baldi et al. (2012) \\
\hline Goldrush $\times \underline{\text { McIntosh Wijcik }}{ }^{\mathrm{b}}(4)$ & 141 & 54 & 84 & 3 & 38 & Baldi et al. (2012) \\
\hline Galaxy $\times \underline{\text { McIntosh Wijcik }}{ }^{\mathrm{b}}(4)$ & 63 & 28 & 34 & 1 & 44 & Baldi et al. (2012) \\
\hline 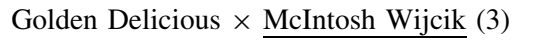 & 399 & 199 & 175 & 25 & 50 & Baldi et al. (2012) \\
\hline Golden Delicious $\times$ McIntosh Wijcik (3) & 898 & 442 & 434 & 22 & 49 & Baldi et al. (2012) \\
\hline
\end{tabular}

The columnar parent is underlined. Plant age is indicated at the last date of phenotypic evaluation where mentioned. Plants were grown on own roots unless indicated otherwise. Only crosses with a total plant number higher than 50 and precise numbers of progeny which was not preselected were included. Other research groups reported an approximation of a 1:1 ratio of columnar versus non-columnar individuals without giving precise numbers (Lee and Looney 1978; Hemmat et al. 1997; Tian 2005; Zhu et al. 2007)

a Pooled data from four crosses

b Plants grafted on M9 rootstocks at 2 years age

c The Telamon $\times$ Braeburn population used by Bai et al. (2012) is the same as the one used by Kenis and Keulemans (2007)

conditions (Tobutt 1985; Brown et al. 2004). The columnar growth habit is still evident when columnar plants are grafted on rootstocks obtained from apple varieties with standard growth. However, the choice of rootstock influences tree height, stem diameter and shoot number (Gelvonauskienë et al. 2006). This can either be caused by the lack of expression of columnar-specific genes in the roots of normal type rootstocks, or by the general influence of the rootstock on plant growth characteristics like tree height, trunk diameter, number of shoots and flowering onset, which can be observed to act upon standard type apple trees after grafting (Seleznyova et al. 2008). As for normal apple trees, dwarfing rootstocks such as M9 are efficient tools for controlling the height and shoot number of columnar apple trees (Gelvonauskienë et al. 2006).
Most of the phenotype characteristics of columnar apple tree varieties provide economic benefits, which is why it has always attracted the attention of breeders and subsequently researchers. Columnar trees can be planted only 0.5-1 m apart in orchards of about 10,000 trees per hectare (Tobutt 1994). They require no staking due to their thick and upright stems and only need to be pruned to control their height. Flowering for the first time takes about 4 years after germination; they have a lifespan of about 20 years and could pay back for the expenses of planting after about 4 years. Furthermore, mechanical harvesters could be used in orchards of this kind, which would save additional cost and labor. It has also been proposed that columnar apple trees be used as space-saving pollinators for conventional orchards or as ornamentation in gardens or streets (Tobutt 1985). 


\section{Mapping and analyzing the Columnar gene region}

The columnar growth habit represents a class of fruit tree architecture on its own (Fideghelli et al. 2003), so it would be highly interesting to determine its molecular basis. Lapins (1969) first proposed that the columnar growth habit could be attributed to the dominant allele of a single gene, Columnar $(\mathrm{Co})$. Since crosses between a columnar and a non-columnar parent usually yield less than $50 \%$ columnar progeny (Table 1), Lapins (1976) suggested that one or two modifier genes might be involved. In contrast, Blazek (1992) deduced that the columnar growth habit might be a double recessive trait. However, the latter hypothesis can be rejected because all commercially available columnar cultivars have been found to be heterozygous for $C o$ (Tian et al. 2005) and crosses between two columnar cultivars have yielded only up to $75 \%$ columnar progeny (Lapins 1976; Meulenbroek et al. 1998). It has been proposed that the deficiency of columnar type trees in the progeny might be caused by a negative influence of $C o$ or a linked gene on the viability of pollen, seeds or emerging seedlings (Meulenbroek et al. 1998). Baldi et al. (2012) found the lack of columnar $F_{1}$ plants to be more pronounced for grafted trees than for trees grown on their own roots, so they concluded that columnar plants might be lost during and/or shortly after the grafting process, which might be amplified when dwarfing rootstocks (in their case M9) are used.

At present, the identity and function of $C o$ as well as its gene product or the type of mutation are still unknown. Similar growth phenotypes have been found for other Rosaceae species such as peach and sour cherry, but their genetic background is either unclear or is distinct from apple (Scorza et al. 2002; Schuster 2009). Since Co is dominant, it is rather unlikely that it is a loss-of-function allele, unless it has a dose-dependent effect. It might carry an amino acid-changing single nucleotide polymorphism (SNP) that causes a gain-of-function in a protein. It might also be a small RNA or a transposon insertion/deletion. Since columnar trees still show their compact growth even when grafted on normal type rootstocks (Fisher 1995), the Co gene product probably exerts its effect in the shoot rather than working up from the roots. Interestingly, overexpression of the Arabidopsis leafy gene in apple trees causes the plants to develop a columnar growth habit (Flachowsky et al. 2010), so Co might somehow be involved in the developmental switch from indeterminate vegetative to determinate reproductive growth. However, these are mere speculations and different scientific approaches are needed to form wellfounded hypotheses.

During the past 15 years, several research groups have tried to determine the chromosomal location of Co using marker analyses so that we can now conclude that it is located on chromosome 10 within the region of 18.51-19.09 Mb (Fig. 3a). At the same time, the genetic linkage map of apple was designed and constantly refined, providing more markers for coupling analyses (Maliepaard et al. 1998; Liebhard et al. 2002, 2003; Silfverberg-Dilworth et al. 2006; Wang et al. 2012). The different research groups used PCR-based markers, mainly random amplification of polymorphic DNA (RAPD), amplified fragment length polymorphism (AFLP) or simple sequence repeats (SSRs), the former two sometimes being converted to sequence characterized amplified region (SCAR) markers.

Before the publication of the apple genome sequence (Velasco et al. 2010), Co was mapped to linkage group (LG) 10 of the apple linkage map and its location was gradually narrowed down to 17.0-19.5 Mb based on seven pivotal markers (Fig. 3b). The very first Co-linked marker, $\mathrm{SSR}^{\mathrm{Co}}$ (Hemmat et al. 1997), whose locus is also amplified by the COL primers designed by Gianfranceschi et al. 1998 and used for linkage analysis by Kenis and Keulemans (2007), seems to be at a distance of at least $20 \mathrm{cM}$ from $C o$. Markers in closer proximity to Co are UBC $818_{1000}$ (Zhu et al. 2007) and $\mathrm{SCAR}_{216}$ (Tian et al. 2005), followed by Hi01a03 (Moriya et al. 2009), SCAR 682 (Tian et al. 2005) and CH03d11 (Fernández-Fernández et al. 2008; Liebhard et al. 2002; Tian et al. 2005). Different values for recombination frequencies and genetic distances of these markers to $C o$ were found by different research groups depending on the apple varieties and the number of individuals used in their linkage studies, but their sequential arrangement remained roughly the same. In a comprehensive marker analysis involving segregating progenies of three crosses and a high number of columnar plants of different varieties, SSR markers CH03d11 and HiO1a03 were found to be the most tightly linked markers flanking $C o$ on either side with maximum genetic distances of 7.4 and $1.4 \mathrm{cM}$, respectively (Moriya et al. 2009). This and two other studies also detected linkage of marker CH02a10, identical to SSRCO F/R (Tian et al. 2005; Bendokas et al. 2007; Moriya et al. 2009), and a fourth study identified SCAR marker SCB82 670 as linked (Kim et al. 2003). However, basic local alignment search tool (BLAST) searches (Altschul et al. 1990) against the annotated apple genome (Velasco et al. 2010) show that the sequences of CH02a10 and SCB $82_{670}$ map to chromosome 3 at about $30 \mathrm{Mb}$. SCB82 670 was later shown to amplify a fragment from the paternal noncolumnar parent of the columnar variety used by Kim et al. (2003), so that it cannot be linked to Co (Tian et al. 2005; Fernández-Fernández et al. 2008; Moriya et al. 2009). In contrast, the reason for co-segregation of $\mathrm{CHO2a10}$ despite the lack of physical coupling remains unclear. It might indicate a genomic region of major importance for maintaining the viability of columnar plants and is thus covered by a selective sweep as proposed by Krost et al. (2013). 
Fig. 3 Molecular markers in the $C o$ gene region. a $C o$ has chromosome 10 at 18.52-19.09 Mb based on the apple genome sequence (Velasco et al. 2010). b Before this publication, $C o$ had already roughly been mapped to 17.0-19.5 Mb. Markers used are shown at the location they have been mapped to via BLAST searches against the 2010). Marker names are in bold, recombination frequencies are in italics, corresponding publications are designated by colors. */** indicates recombination frequencies found for different varieties. Horizontal lines above the markers in (a) designate the newly delimited $C o$ regions by Bai et al. (2012); Moriya et al. (2012) and Baldi et al. (2012) recently been mapped on apple genome (Velasco et al.

a

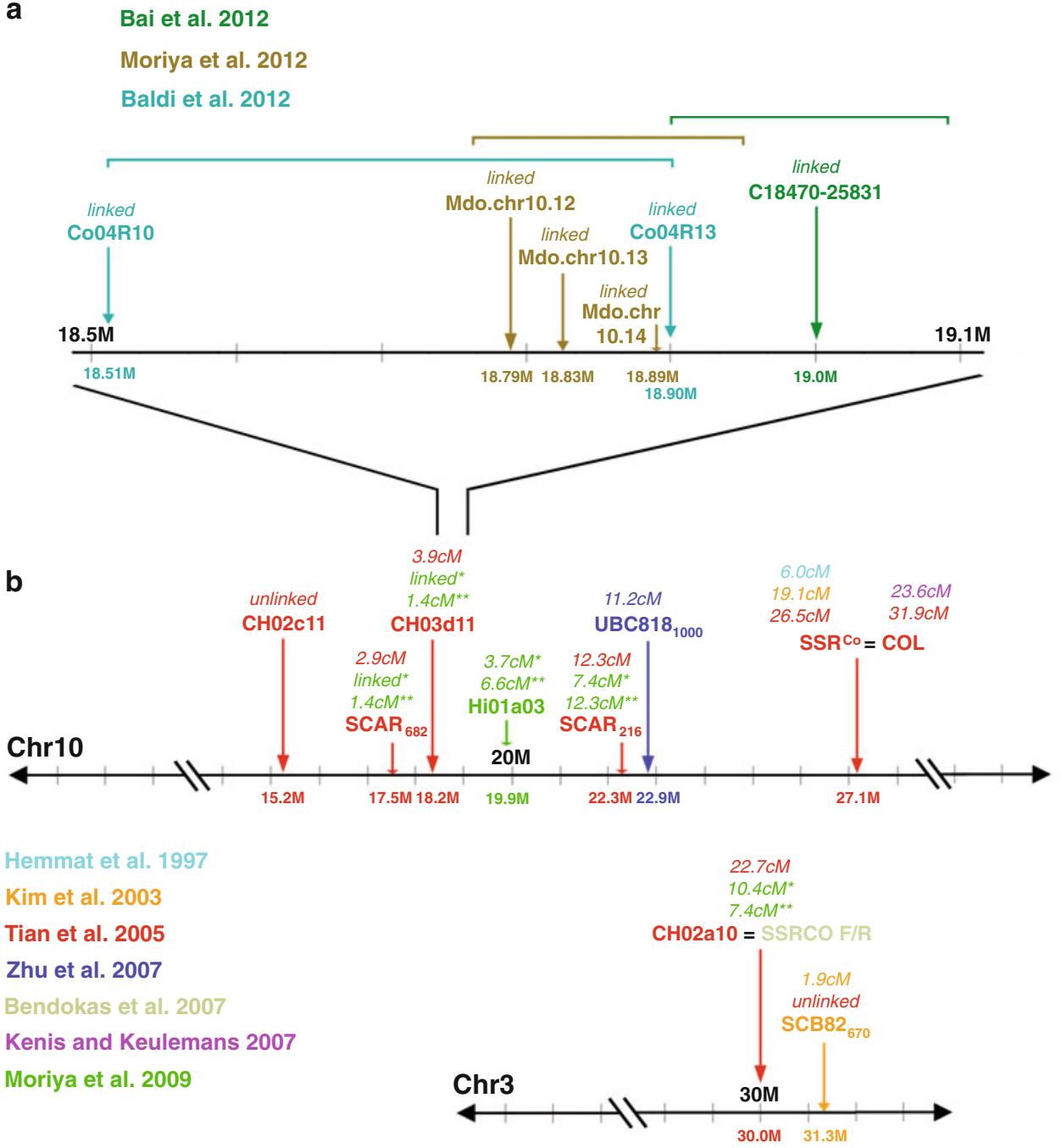

Alternatively, the genomic contig might have been incorrectly assembled to chromosome 3 .

Since the Golden Delicious genome sequence was released in 2010 (Velasco et al. 2010), the possibility of generating sequence-based markers has significantly simplified and accelerated the fine-mapping of the Co region (Fig. 3a). Bai et al. (2012) developed 88 SSR markers based on genomic apple contigs originating from chromosome 10 around the target region as well as from two unanchored contigs which they identified as being located within this region via a synteny approach using the peach genome. They used four segregating progenies as well as 290 columnar selections to evaluate the quality of 18 already published markers and the new SSR markers. 47 plants showing recombination between $\mathrm{SCAR}_{682}$ and $\mathrm{Hi} 01 \mathrm{a} 03$ as well as one double-recombinant were used for screening with the new markers, and 6 key recombinants finally served to delimit the Co gene region to $193 \mathrm{~kb}$ between markers $\mathrm{C} 1753-3520$ at $18.90 \mathrm{Mb}$ and C762922009 at $19.09 \mathrm{Mb}$. Marker C18470-25831 (19.0 Mb) was found to co-segregate with $C o$. The newly delimited region contains 20 annotated genes and 7 predicted genes, 3 of which code for homologs of Lateral Organ Boundaries Domain transcription factors in Arabidopsis (Majer and Hochholdinger 2011) and were thus considered the most likely candidates for $C o$ (Bai et al. 2012).

Moriya et al. (2012) also developed SSR markers based on the Golden Delicious genome sequence and used 1,000 $F_{1}$ individuals from 31 populations for linkage analysis. They delimited the $C o$ gene region to $196 \mathrm{~kb}$, a similar size as in Bai et al. (2012). However, the markers developed by Moriya et al. (2012) flanking this region are located at $18.76 \mathrm{Mb}$ (Mdo.chr10.11) and 18.96 Mb (Mdo.chr10.15). Additionally, markers Mdo.chr10.12 (18.79 Mb), Mdo.chr10.13 $(18.83 \mathrm{Mb})$ and Mdo.chr10.14 (18.89 Mb) co-segregated with $C o$.

In a third study, Baldi et al. (2012) first used three adult segregating progenies ( $301 \mathrm{~F}_{1}$ plants in total) and the early published markers to roughly define the $C o$ gene region and then refined it with two large populations treated as a 
single segregating progeny of 1,250 individuals which they subjected to genotypic mapping with seven newly designed SSR markers. Co was localized between co-mapping markers Co04R10 and Co04R11 on one side and Co04R 13 on the other side, which yielded a genomic region of $0.56 \mathrm{cM}$, corresponding to $393 \mathrm{~kb}$ at $18.52-18.90 \mathrm{Mb}$. A thorough open reading frame analysis revealed 36 potential genes within this region, several of which code for transcription factors of the MYB, basic helix-loop-helix and AP2/ERF classes, members of which play roles in the regulation of plant architecture. The target region overlaps with the region identified by Moriya et al. (2012), but does not span the chromosomal location predicted for $C o$ by Bai et al. (2012). Furthermore, marker C18470-25831, which Bai et al. (2012) found to be linked to $C o$, showed three recombinants in the mapping population of Baldi et al. (2012). Possible reasons for the different locations of the $C o$ region boundaries are that the three research groups used different apple genotypes which possibly have distinct recombination frequencies and that the marker defining the right border of Bai et al. (2012) originates from one of the contigs which was unanchored in the genome project, so its precise location is not well-founded. There might also have been some difficulties in the phenotypic classification of individual plants. Taken together, $C o$ is most likely located between 18.76 and $18.9 \mathrm{Mb}$, a region comprising approximately 30 annotated genes, none of which have so far been identified as having a profound influence on plant architecture.

Detailed analyses of the Co target region are already underway: Baldi et al. (2012) constructed a bacterial artificial chromosome (BAC) library based on genomic DNA extracted from leaves of McIntosh Wijcik with an average insert size of $145 \mathrm{~kb}$ and found ten BAC clones originating from the Co target region, of which a minimum of four clones is needed to span the entire chromosomal section of interest. These clones will enable a comparative analysis of the columnar and the non-columnar allele within the next months.

(Otto et al. 2013) also constructed BAC libraries using genomic DNA of the heterozygous columnar cultivar Procats 28 . They obtained more than 100,000 clones with an average insert size of $27 \mathrm{~kb}, 37$ of which could be assigned to chromosome 10 at $18.0-19.0 \mathrm{Mb}$. Assembly of their sequences yielded two metacontigs of 590 and $190 \mathrm{~kb}$ in size. Comparison of these sequences to the Golden Delicious reference has already been used to create four Indel-based markers linked to $\mathrm{Co}$ and is ongoing to detect more differences between the genomic organization of columnar and non-columnar apple trees.

Alleles showing consistent differences between columnar and non-columnar cultivars can be expected to be further analyzed and prepared for transformation in the near future.
Analysis of quantitative trait loci in the Columnar gene region

To gain a better understanding of the many distinct but interconnected factors that influence plant architecture, mapping of QTLs associated with plant growth on progenies of columnar trees have been carried out alongside marker analyses. Several research groups have found clusters of QTLs associated with plant architecture on LG 10 in the vicinity of $\mathrm{Co}$. For 172 juvenile apple trees of the cross McIntosh Wijcik $\times$ NY 75441-58, internode number in year 1 and year 2 of their life, the stem base diameter increment in year 1 and year 3 as well as branch number and internode length in year 1 were associated with regions located on LG 10 at roughly the locus of the marker P459z (Conner et al. 1998). The terminal bearing $(\mathrm{Tb})$ locus correlating with branching habit and influencing vegetative bud break (Lawson et al. 1995) also maps close to this region (Conner et al. 1998); however, it is distinct from Co. Based on the investigations of a Telamon $\times$ Braeburn progeny comprising 257 individuals, a QTL cluster for a wide range of phenotype characteristics such as total growth increment, total branch number and branch length, internode length, main axis growth rate and main axis height increment was detected on LG 10 (Kenis and Keulemans 2007). The authors deduced clustering of different genes or a pleiotropic effect of a single gene, preferring the latter. They also found the Co gene influence on branch length (apical control) to be more pronounced than its influence on branch number (apical dominance).

Using the same mapping population, loci for plant architectural traits and QTLs associated with fruit quality were both found on the same linkage group as Co (Davey et al. 2006; Kenis et al. 2008). This includes QTLs for fruit flesh weight, flesh L-ascorbic acid content, soluble sugar, firmness and acidity. Some of these QTLs account for up to $60 \%$ of the phenotypic differences observed. A possible theory is that this specific area on LG 10 controls aspects of plant growth and development and these then have pleiotropic effects which affect fruit quality traits (Kenis et al. 2008). This led Moriya et al. (2009) to the conclusion that Co might be tightly linked to genes conferring low fruit quality, and thus it would be desirable to use gene technology for the production of new columnar cultivars because classical breeding approaches would in most cases transfer $C o$ in combination with these unpopular traits.

In summary, the $C o$ gene region on LG 10 seems to be pivotal for plant growth and development, either due to the influence of one gene (possibly $\mathrm{Co}$ ) or due to the combined action of several genes in a cluster. In any case, changes in growth habit would most likely be accompanied by alterations in the phytohormone levels of the plant. 


\section{Phytohormone levels in columnar apple trees}

Several attempts have been made to correlate the columnar growth habit with changes in phytohormone levels. Unfortunately, phytohormone concentrations are difficult to measure and they show extensive variations depending on the age of the plant, the season and the environmental factors. Additionally, it is challenging to decide whether changes in hormone levels are a cause or a consequence of the columnar growth habit. Only four hormone groups have been investigated so far in the columnar apple, and direct connections between the results and the phenotypic manifestation are scarce.

Since columnar apple trees form short fruit spurs rather than long lateral branches, it was suggested that they might have stronger apical dominance and apical control than normal type apple trees and thus a focus has been put on the IAA levels in columnar plants. Measurements of IAA content with the indole-pyrone fluorescence method indicated that in shoot tips, free IAA levels correlated positively with the degree of compactness. Additionally, axillary buds of columnar apple trees have a higher ratio of free IAA to total IAA than normal type apple trees due to a lower level of conjugated IAA (Looney and Lane 1984). However, when the polar auxin transport is blocked by application of the inhibitor triiodobenzoic acid, branch attachment angles and the numbers of spurs on both genotypes were increased, which contradicts the hypothesis of stronger apical dominance in columnar apple trees (Looney and Lane 1984). The authors concluded that in McIntosh Wijcik, an IAA-hydrolyzing enzyme might be active at the time when lateral buds are formed, which results in very strong buds easily breaking dormancy and growing into spurs during the following season. Due to the competition for nutrients among the axillary organs, fruit spurs rather than long branches are formed (Looney and Lane 1984). However, it seems more likely that the preferential formation of spurs compared with lateral shoots is caused by a lack of growth-promoting factors such as GA. Watanabe et al. $(2004,2006,2008)$ measured the IAA concentration of the central and axillary shoots (arising from just below the previous year's pruning cut) of 3- to 5 -year-old columnar trees grafted on seedling rootstocks using gas chromatography-mass spectrometry-selected ion monitoring (GC-MS-SIM) and found the central leader to have more IAA than the lateral branches. Furthermore, in July, total IAA was higher in axillary shoots of columnar type apple trees than in axillary shoots of 1- or 2-year-old branches of 38-year-old normal type McIntosh trees on seedling rootstocks, which might be correlated with the observation that the former still grow vigorously until October, whereas the latter already cease growing in July. No significant differences were found with respect to the total IAA content in axillary shoots of columnar and normal type apple trees during the entire growth season. Unfortunately, since Watanabe et al. (2004, 2006, 2008) compared 3- to 5-year-old columnar trees of the varieties Maypole and Tuscan (grown on seedling rootstocks) to normal McIntosh trees at 38-40 years of age (also grown on seedling rootstocks), the differences might be a result of age rather than of growth habit. Furthermore, the number of plants analyzed was low (maximum of $n=15$ ). Therefore, it would be interesting to compare IAA levels within a high number of columnar and non-columnar trees of the same age. Since it is usually the IAA transport within the shoot and not the absolute IAA level that regulates growth processes, measuring the IAA movement within the stem of columnar apple trees would also be of great interest. In summary, the results indicate a higher IAA content in columnar apple trees, which would be in agreement with higher apical control.

Focusing on CKs, in the soybean hypocotyl section bioassay, McIntosh Wijcik was found to have significantly higher levels of zeatin-like growth substances than other McIntosh strains (Looney and Lane 1984). In GC-MS-SIM experiments of the same plants as mentioned above, the endogenous concentration of zeatin riboside, the predominant CK associated with bud burst in apple, was found to be higher in both apical and lateral shoots of columnar trees during the course of a year (Watanabe et al. 2004, 2006). This could explain the high number of spurs. However, like in the IAA measurements, the authors again only compared a low number of 3- to 5-year-old columnar trees, which grow vigorously, with 38- to 40-year-old normal trees, which are at the end of their growth period, so further studies comparing a statistically significant number of trees of the same age would be needed. The ratio of isopentenyl adenosine to total $\mathrm{CK}$ was highest in lateral shoots and buds of normal trees in July and of columnar ones in November, so it is probably associated with the onset of winter dormancy (Watanabe et al. 2008).

Growth of normal apple trees after exogenous application of CKs follows an optimum curve: the higher the amount of CKs given, the more vigorously does the plant grow when growth is defined as the number of shoots initiated which develop to shoots longer than $1 \mathrm{~cm}$ or as culture weight gain for in vitro cultures. If the concentration exceeds the optimum level, plant growth is more and more inhibited. In vitro cultures of columnar apple trees show a similar reaction of culture weight gain to exogenously applied CKs, and the optima for 6-benzyladenine (BA) $(5 \mu \mathrm{M})$ and thidiazuron $(3 \mu \mathrm{M})$ are similar to the ones of normal type apple trees (Lane and Looney 1982). However, at very low BA concentrations, normal type apple cultures on modified Murashige and Skoog medium grow better, whereas columnar apple cultures on modified 
Murashige and Skoog medium show a significantly higher tolerance to supra-optimal concentrations of CKs: the maximum concentrations at which columnar and normal type plants still grow are 25 (Sarwar et al. (1998): $50 \mu \mathrm{M}$ ) versus $5 \mu \mathrm{M}$ for BA, 60 versus $25 \mu \mathrm{M}$ for kinetin, 25 versus $20 \mu \mathrm{M}$ for 2-isopentyladenine, and 40 versus $25 \mu \mathrm{M}$ for thidiazuron, respectively (Lane and Looney 1982; Sarwar et al. 1998). To perform shoot regeneration from leaf explants, higher concentrations of CKs are needed for columnar apple plants than for normal ones (Sarwar and Skirvin 1997). The authors concluded that either columnar plants can metabolize excess levels of CKs or they compensate for it by adjusting the level of other growth regulators (Lane and Looney 1982). Another explanation would be that columnar apples do not take up excessive amounts of CKs, because they have thicker cell layers than standard type apple trees (Sarwar et al. 1998).

Taken together, the levels of CKs seem to be higher in columnar than in normal apples and columnar apple trees seem to have an altered CK metabolism. Watanabe et al. (2008) hypothesized that the large leaf area of columnar apple trees might contribute in part to the increased production of CKs. However, as CKs are predominantly produced in the roots and to a smaller extent in young leaves only, this explanation seems rather unlikely.

Some of the phenotype characteristics of columnar trees such as stunted growth and dark green leaves resemble characteristics of GA-deficient mutants (Koornneef and Veen 1980; Talon et al. 1990; Sun and Kamiya 1994; Peng and Harberd 1997). Thus, GAs constitute another class of phytohormones that has attracted the attention of researchers focusing on columnar growth. Looney and Lane (1984) summarized their findings on GA levels in columnar apple trees as follows: in the dwarf pea bioassay, shoot tip extracts of columnar apple seedlings did not promote growth as much as those of normal type seedling, indicating lower GA-like activity. Low polar GAs were also found in actively growing shoot tips of McIntosh Wijcik when examined using silica gel partition column chromatography and the dwarf rice bioassay. However, polar GAs are not necessarily bioactive (Atzorn and Weiler 1983). After $\mathrm{GA}_{3}$ was applied exogenously, columnar seedlings showed a greater percentage of growth increase, but still did not reach the height of their normal type counterparts. The conclusion was that low GA levels probably correlate with dwarfing of McIntosh Wijcik rather than its spurriness, and dwarfing is a phenotype characteristic independent of compact growth (Looney and Lane 1984).

With regard to $\mathrm{ABA}$, lower levels of free cis-ABA were found in actively growing shoot tips including five expanded terminal leaves of young columnar progeny of McIntosh Wijcik crosses with three different non-columnar varieties grafted on M7 than in their normal type siblings (Lee and Looney 1977). These data were statistically significant on a per shoot tip basis, whereas data on a fresh weight basis had a tendency toward lower levels, but no statistical significance was achieved. The bourse buds of McIntosh Wijcik trees also had less free and conjugated ABA than those of standard McIntosh on a fresh weight basis, even though, due to their larger size, the total ABA amount per bud was higher (Looney and Lane 1984). ABA in general is higher per fresh weight in rapidly elongating shoots (Feucht et al. 1974), so the lower ABA levels are probably a consequence-not the cause-of the slower growth of fruit spurs compared with lateral shoots (Looney and Lane 1984).

In the seeds and early seedlings of a progeny of controlled crosses of McIntosh Wijcik with a non-columnar variety, levels of ABA and GA were similar for both varieties, indicating that the hormonal differences that characterize the compact seedlings are probably established at a later stage of development (Lee and Looney 1978).

Taken together, these results suggest that columnar apple varieties do show differences in phytohormone levels, but most of them are fairly subtle, and only hypotheses of their correlation with the phenotype can be made. Due to the high IAA levels and lower IAA/CK ratio of shoots, the apical dominance of columnar trees is higher than that of normal type trees and thus they do not produce long axillary shoots. Fruit spurs are produced because of high levels of CKs in combination with low levels of ABA, which favors bud break, but slows extension growth. Only in some occasions (e.g., when the central leader is damaged) are a few spurs able to overcome the apical dominance and grow out. The lower levels of GA might inhibit long extension growth and are related to the dwarfing of most columnar trees.

\section{Transcriptome analyses of columnar type apple trees}

Another approach to unravel the function of $C o$ is the analysis of transcriptional changes in columnar compared to normal type apple trees. Taking into consideration of the fundamental phenotypic changes, it can be expected that the expression levels of several genes are altered, but it is difficult to decide on one specific pathway which is definitely influenced, so the method of choice is a whole transcriptome study.

Three recent studies have analyzed the transcriptomes of columnar and normal type apple trees via RNA-seq. Zhang et al. (2012) collected new lateral shoots of 4-year-old columnar and standard seedlings of the progeny of Fuji $\times$ Telamon. They used three time points between May 
and July 2010 and pooled the material of the three time points to obtain two samples, one from columnar and one from non-columnar apple. They performed a total RNA extraction and mRNA purification, and generated about 4 million reads for each sample in an Illumina HiSeq 2000 next generation sequencing run. $80 \%$ of the reads were mapped to the apple genome (Velasco et al. 2010). Assembling yielded about 57,000 non-redundant unigenes with contigs having an $\mathrm{N}_{50}$ of about 420 . On comparing differential gene expression based on reads per kilobase per million mapped reads values, 5,237 genes were found to be differentially expressed by more than twofold, 2,704 being upregulated and 2,533 being downregulated in the columnar versus the normal type apple. Of the differentially expressed genes, $15 \%$ were involved in the biosynthesis of secondary metabolites, and $24 \%$ had a role in metabolic pathways, some of them being key players in GA, IAA and BR biosynthesis. Unfortunately, no specific genes or their precise regulation were mentioned. In addition, 287 genes involved in pathways crucial for the regulation of plant architecture were identified, most likely based on the function of their homologs identified by BLAST searches (although the authors did not mention how they identified their function), but again no values for their expression were given. Among these 287 genes, 31 were mapped to chromosome 10, and 25 were Gibberellic-Acid Insensitive, Repressor of Gibberellic-Acid Insensitive and Scarecrow (GRAS) transcription factors like DELLAs, which play a role in the gibberellin signal transduction. Some of these genes of interest are intended to be transferred into Gala apple trees via Agrobacterium-mediated transformation.

Krost et al. (2012) also compared gene expression levels of columnar versus normal type apple trees using RNAseq. They collected shoot apical meristems of spurs of columnar Procats 28 (P28), which has a Telamon ancestor, and of branches of normal A14-190-93 (A14), isolated the total RNA and purified the mRNA followed by mRNA amplification. May 2009 and September 2009 were used as time points for A14 and P28, respectively. 454 as well as Illumina sequencings were performed on these samples, and about 250,000 reads were obtained for each 454 library as well as about 80 million reads for each Illumina library. They conducted BLAST searches of the raw sequences against all annotated Malus $x$ domestica proteins (MDPs) and compared those to UniProtKB. Subsequently, differential expression was determined and differentially expressed genes were grouped into distinct categories. Genes of categories representing light reactions, mitochondrial electron transport, lipid metabolism and cell wall modification (expansins and xyloglucan endotransglucosylases/hydrolases) were significantly downregulated in the columnar variety, whereas another group of genes involved in cell wall modification, terpenoid and tryptophan synthesis (the precursors of IAA biosynthesis) were upregulated. Genes involved in DNA synthesis, RNA processing and protein synthesis were downregulated, which correlates with reduced growth of the columnar plants, whereas those involved in transport and protein modification were upregulated. Considering phytohormone metabolism, genes of biosynthesis and signal transduction of IAA and jasmonates were induced. The opposite was reported for genes associated with GA biosynthesis and signal transduction. These results agree with the findings on phytohormone levels described in the previous section. Furthermore, there were hints to a cell cycle arrest in G2 in columnar apples, which would result in a lower number of cells and would thus explain the stunted growth. In summary, results suggested an alteration in cell wall and cell membrane formation resulting in smaller cells which in combination with the cell cycle arrest would lead to short spurs instead of long branches. Functions associated with membrane integrity such as transport, photosynthesis and mitochondrial electron transport also seemed to be changed, which were considered to be consequences of columnar growth.

In a second gene expression study, Krost et al. (2013) narrowed down the genes of interest to those involved in phytohormone biosynthesis, signaling and transport. At the same time, they expanded the amount of data to six Illumina data sets, totaling almost 500 million reads, from three different time points (May 2009, September 2009 and July 2010) and validated their data with results of a microarray chip hybridized with RNAs of four collection dates between April and May as well as of quantitative real-time PCR carried out on RNA isolated from in vitro cultures of P28 and A14. It is doubtful whether in vitro cultures represent a suitable model for the study of transcriptional changes associated with altered tree architecture since they do not reach the same age and architectural complexity as trees, and in vitro-grown leaves have been shown to have altered methylation patterns compared with field-grown leaves, which might influence gene expression (Li et al. 2002). However, since the in vitro cultures were only used to confirm results that had already been obtained by RNA-seq and microarray analyses of in vivo material in this study, they provide the possibility to test the transferability of the results to plants grown under tightly controlled conditions. Of 619 genes found to be significantly differentially regulated by Krost et al. (2013), 16 were detected to be involved in the regulation of all major phytohormone groups, as can be expected for a phenotype affecting many different aspects of plant growth. An integration of the results suggested that an increase of IAA levels together with a higher basipetal IAA transport (due to upregulation of Auxin Resistant and Pin-formed 1) is responsible for the high level of apical dominance and 
apical control of columnar apple trees. This is overcome by the elevated level of CKs when spurs are formed; however, they cease their elongation growth early. Additionally, the complex interplay between growth-promoting factors (IAA, CKs and apolar GAs) and growth-inhibiting factors (JAs and XTHs), which all showed upregulation in columnar trees in this study, is responsible for the achievement of normal plant height. Another 16 genes showing constant differential regulation in at least two of the three gene expression studies conducted were analyzed with regard to their chromosomal location. Five of them were found to reside in chromosome 10 , indicating a statistically approved enrichment of differentially regulated genes in the $C o$ gene vicinity. Four of them are associated with phytohormonal regulations, so Krost et al. (2013) drew the conclusion that the region is most likely covered by a selective sweep due to the influence of the $C o$ gene.

Further time course gene expression experiments will be necessary to validate and increase our knowledge about the function of the $C o$ gene product. It would also be helpful to expand these analyses to other tissues and developmental stages, yielding a comprehensive picture of the physiological state of the plant.

\section{Conclusion}

While a number of individual genes and signaling molecules regulating plant architecture have already been identified in model plants, it has not yet been possible to create a concise picture of the whole process since some key players still remain elusive and knowledge about the interaction of the individual pathways is scarce. The columnar growth habit of apple is a natural mutant showing altered plant shape and thus might be the key to an important factor in the regulation of tree architecture. During the past few years, a lot of progress in the understanding of the columnar growth habit has been made. It is caused by the dominant allele of the Columnar gene on chromosome 10 which probably influences IAA, CK and GA metabolism and signal transduction leading to stunted growth and nearly absent branching. Molecular markers created with the help of the apple genome sequence (Velasco et al. 2010) have successfully been used to fine map the Co locus to 18.51-19.09 Mb on chromosome 10. Since in-depth analysis of this region is already underway, disclosure of the identity of $\mathrm{Co}$ can be anticipated for the near future. Additional comparisons of growth regulator concentrations in columnar and normal type apple trees as well as in-depth transcriptome analyses would facilitate the discovery of $C o$ function and affected signal pathways.
Acknowledgments We are grateful to Prof. E. R. Schmidt for the critical review of the manuscript, to Ramona Petersen for linguistic proofreading, and to Bastienne Brauksiepe for allowing us to take pictures of the apple trees at the Geisenheim University. We apologize to colleagues whose work could not be cited due to space limitations. Our work was supported by grants of the Federal Ministry of Agriculture and Nutrition (No. 511-06.01-28-1-43.042-07 and no. 313-06.01-28-1-43.042-07).

Conflict of interest The authors declare that they have no conflict of interest.

\section{References}

Abe M, Kobayashi Y, Yamamoto S, Daimon Y, Yamaguchi A, Ikeda Y, Ichinoki H, Notaguchi M, Goto K, Araki T (2005) FD, a bZIP protein mediating signals from the floral pathway integrator FT at the shoot apex. Science 309:1052-1056

Aguilar-Martínez JA, Poza-Carrión C, Cubas P (2007) Arabidopsis BRANCHED1 acts as an integrator of branching signals within axillary buds. Plant Cell 19:458-472

Agusti J, Herold S, Schwarz M, Sanchez P, Ljung K, Dun EA, Brewer PB, Beveridge CA, Sieberer T, Sehr EM, Greb T (2011) Strigolactone signaling is required for auxin-dependent stimulation of secondary growth in plants. PNAS 108:20242-20247

Aida M, Ishida T, Tasaka M (1999) Shoot apical meristem and cotyledon formation during Arabidopsis embryogenesis: interaction among the CUP-SHAPED COTYLEDON and SHOOT MERISTEMLESS genes. Development 126:1563-1570

Altschul SF, Gish W, Miller W, Myers EW, Lipman DJ (1990) Basic local alignment search tool. J Mol Biol 215:403-410

Asano K, Miyao A, Hirochika H, Kitano H, Matsuoka M, Ashikari M (2010) SSD1, which encodes a plant-specific novel protein, controls plant elongation by regulating cell division in rice. $\mathrm{P}$ Jpn Acad B Phys 86(3):265-273

Atzorn R, Weiler EW (1983) The immunoassay of gibberellins. Planta 159:7-11

Baba K, Karlber A, Schmidt J, Schrader J, Hvidsten TR, Bako L, Bhalerao RP (2011) Activity-dormancy transition in the cambial meristem involves stage-specific modulation of auxin response in hybrid aspen. PNAS 108:3418-3423

Bai T, Zhu Y, Fernández-Fernández F, Keulemans J, Brown S, Xu K (2012) Fine genetic mapping of the Co locus controlling columnar growth habit in apple. Mol Genet Genomics 287:437-450

Baldi P, Wolters PJ, Komjanc M, Viola R, Velasco R, Salvi S (2012) Genetic and physical characterisation of the locus controlling columnar habit in apple (Malus $\times$ domestica Borkh.). Mol Breeding. doi: 10.1007/s11032-012-9800-1

Bao Y, Dharmwardhana P, Arias R, Allen MB, Ma C, Strauss SH (2009) WUS and STM-based reporter genes for studying meristem development in poplar. Plant Cell Rep 28:947-962

Bendokas V, Gelvonauskienë D, Gelvonauskis B, Vinskienë J, Stanys V (2007) Identification of apple columnar hybrids in juvenile phase using molecular markers. Scientific Works of the Lithuanian Institute of Horticulture and Lithuanian University of Agriculture 26(3):289-295

Benková E, Michniewicz M, Sauer M, Teichmann T, Seifertová D, Jürgens G, Friml J (2003) Local, efflux-dependent auxin gradients as a common module for plant organ formation. Cell 115:591-602 
Bennett T, Sieberer T, Willett B, Booker J, Luschnig C, Leyser O (2006) The Arabidopsis MAX pathway controls shoot branching by regulating auxin transport. Curr Biol 16:553-556

Björklund S, Antti H, Uddestrand I, Moritz T, Sundberg B (2007) Cross-talk between gibberellin and auxin in development of Populus wood: gibberellin stimulates polar auxin transport and has a common transcriptome with auxin. Plant J 52:499-511

Blazek J (1992) Segregation and general evaluation of spur type or compact growth habits in apples. Acta Hort 317:71-79

Böhlenius H, Huang T, Charbonnel-Campaa L, Brunner AM, Jansson S, Strauss SH, Nilsson O (2006) CO/FT regulatory module controls timing of flowering and seasonal growth cessation in trees. Science 312:1040-1043

Brand U, Fletcher JC, Hobe M, Meyerowitz EM, Simon R (2000) Dependence of stem cell fate in Arabidopsis on a feedback loop regulated by $C L V 3$ activity. Science 289:617-619

Brewer PB, Dun EA, Ferguson BJ, Rameau C, Beveridge CA (2009) Strigolactone acts downstream of auxin to regulate bud outgrowth in pea and Arabidopsis. Plant Physiol 150:482-493

Brown CL, McAlpine RG, Kormanik PP (1967) Apical dominance and form in woody plants: a reappraisal. Am J Bot 54:153-162

Brown SK, Maloney KE, Hemmat M, Aldwinckle HS (2004) Apple breeding at Cornell: genetic studies of fruit quality, scab resistance and plant architecture. Acta Hort 663:693-698

Brunner AM, Rottmann WH, Sheppard LA, Krutovskii K, DiFazio SP, Leonardi S, Strauss SH (2000) Structure and expression of duplicate AGAMOUS orthologues in poplar. Plant Mol Biol 44:619-634

Buban T (1996) In: Nieki J, Soltesz M (eds) Floral biology of temperate zone fruit trees and small fruits, Akademiai Kiado, Budapest, pp 3-54

Busch MA, Bomblies K, Weigel D (1999) Activation of a floral homeotic gene in Arabidopsis. Science 285:585-587

Ceulemans R, Stettler RF, Hinckley TM, Isebrands JG, Heilmann PE (1990) Crown architecture of Populus clones as determined by branch orientation and branch characteristics. Tree Physiol 7:157-167

Chandler JW (2009) Auxin as compère in plant hormone crosstalk. Planta 231:1-12

Chen X, Zhang Z, Liu D, Zhang K, Li A, Mao L (2010) SQUAMOSA promoter-binding protein-like transcription factors: star players for plant growth and development. J Integr Plant Bio 52:946-951

Chen Y, Yordanov YS, Ma C, Strauss S, Busov VB (2013) DR5 as a reporter system to study auxin response in Populus. Plant Cell Rep 32:453-463

Clark SE, Running MP, Meyerowitz EM (1993) CLAVATA 1, a regulator of meristem and flower development in Arabidopsis. Development 119:397-418

Clark SE, Running MP, Meyerowitz EM (1995) CLAVATA 3 is a specific regulator of shoot and floral meristem development affecting the same processes as CLAVATA 1. Development pp 2057-2067

Cline MG (1991) Apical dominance. Bot Rev 57:318-358

Cline MG (1997) Concepts and terminology of apical dominance. Am J Bot 84:1064-1069

Cline MG, Dong-Il K (2002) A preliminary investigation of the role of auxin and cytokinin in sylleptic branching of three hybrid poplar clones exhibiting contrasting degrees of sylleptic branching. Ann Bot Lond 90:417-421

Conner PJ, Brown SK, Weeden NF (1998) Molecular marker analysis of quantitative traits for growth and development in juvenile apple trees. Theor Appl Genet 96:1027-1035

Cooke JEK, Eriksson ME, Junttila O (2012) The dynamic nature of bud dormancy in trees: environmental control and molecular mechanisms. Plant Cell Environ 35:1707-1728
Costes E, Guédon Y (2002) Modelling branching patterns on 1-yearold trunks of six apple cultivars. Ann Bot Lond 89:513-524

Costes E, Lauri PE, Regnard JL (2006) Analyzing fruit tree architecture: implications for tree management and fruit production. Hortic Rev 32:1-61

Davey MW, Kenis K, Keulemans J (2006) Genetic control of fruit vitamin C contents. Plant Physiol 142:343-351

Dayan J, Voronin N, Gong F, Sun T-P, Hedden P, Fromm H, Aloni R (2012) Leaf-induced gibberellin signaling is essential for internode elongation, cambial activity, and fiber differentiation in tobacco stems. Plant Cell 24(1):66-79

De Wit I, Pauwels E, Keulemans J (2000) Different growth habits in apple and correlation between growth characteristics in progenies with a common Co-gene parent. Acta Hortic pp 325-330

Domagalska MA, Leyser O (2011) Signal integration in the control of shoot branching. Nat Rev 12:211-221

Domagalska MA, Sarnowska E, Nagy F, Davis SJ (2010) Genetic analyses of interactions among gibberellin, abscisic acid, and brassinosteroids in the control of flowering time in Arabidopsis thaliana. PLoS One 5:e14012

Douglas SJ, Chuck G, Dengler RE, Pelecanda L, Riggs CD (2002) KNAT1 and ERECTA regulate inflorescence architecture in Arabidopsis. Plant Cell 14:547-558

Du J, Mansfield SD, Groover AT (2009) The Populus homeobox gene ARBORKNOX 2 regulates cell differentiation during secondary growth. Plant J 60:1000-1014

Durbak A, Yao H, McSteen P (2012) Hormone signaling in plant development. Curr Opin Plant Biol 15:92-96

Eaton GW, Lapins KO (1970) Identification of standard and compact apple trees by discriminant function analysis. J Appl Ecol $7: 267-272$

Edwards KD, Anderson PE, Hall A, Salathia NS, Locke JCW, Lynn JR, Straume M, Smith JQ, Millar AJ (2006) FLOWERING LOCUS $C$ mediates natural variation in the high-temperature response of the Arabidopsis circadian clock. Plant Cell 18:639-650

Elias AA, Busov VB, Kosola KR, Ma C, Etherington E, Shevchenko O, Gandhi H, Pearce DW, Rood SB, Strauss SH (2012) Green revolution trees: semidwarfism transgenes modify gibberellins, promote root growth, enhance morphological diversity, and reduce competitiveness in hybrid poplar. Plant Physiol 160:1130-1144

Eriksson ME, Moritz T (2002) Day length and spatial expression of a gibberellin 20-oxidase isolated from hybrid aspen (Populus tremula L. $\times$ P. tremuloides Michx.). Planta 214:920-930

Eriksson ME, Israelsson M, Olsson O, Moritz T (2000) Increased gibberellin biosynthesis in transgenic trees promotes growth, biomass production and xylem fiber length. Nat Biotech 18:784-788

Farré EM (2012) The regulation of plant growth by the circadian clock. Plant Biol 14:401-410

Fernández-Fernández F, Evans KM, Clarke JB, Govan CL, James CM, Marič S, Tobutt KR (2008) Development of an STS map of an interspecific progeny of Malus. Tree Genet Genomes 4:469-479

Feucht W, Khan MZ, Daniel P (1974) Abscisic acid in prunus trees: isolation and the effect on growth of excised shoot tissue. Physiol Plantarum 32:247-252

Fideghelli C, Sartori A, Grassi F (2003) Fruit tree size and architecture. Acta Hort 622:279-293

Fisher DV (1969) Spur-type strains of McIntosh for high density plantings. British Columbia Fruit Growers' Association Quarterly Report 14:3-10

Fisher DV (1995) The "Wijcik spur McIntosh". Fruit Var J 49:212-213 
Flachowsky H, Hättasch C, Höfer M, Peil A, Hanke MV (2010) Overexpression of $L E A F Y$ in apple leads to a columnar phenotype with shorter internodes. Planta 231:251-263

Friml J, Palme K (2002) Polar auxin transport-old questions and new concepts? Plant Mol Biol 49:273-284

Gälweiler L, Guan C, Müller A, Wisman E, Mendgen K, Yephremov A, Palme K (1998) Regulation of polar auxin transport by AtPIN1 in Arabidopsis vascular tissue. Science 282:2226-2230

Garrison R (1955) Studies in the development of axillary buds. Am J Bot 42:257-266

Gelvonauskienë D, Gelvonauskis B, Sasnauskas A (2006) Impact of rootstock on columnar apple tree growth in a nursery. Scientific Works of the Lithuanian Institute of Horticulture and Lithuanian University of Agriculture 25:51-56

Gelvonauskis B, Brazaitytë A, Sasnauskas A, Duchovskis P, Gelvonauskienë D (2006) Morphological and physiological characteristics of columnar apple trees. Scientific Works of the Lithuanian Institute of Horticulture and Lithuanian University of Agriculture 25:350-356

Gianfranceschi L, Seglias N, Tarchini R, Komjanc M, Gessler C (1998) Simple sequence repeats for the genetic analysis of apple. Theor Appl Genet 96:1069-1076

Gocal GF, King RW, Blundell CA, Schwartz OM, Andersen CH, Weigel D (2001) Evolution of floral meristem identity genes. Analysis of Lolium temulentum genes related to APETALA 1 and LEAFY of Arabidopsis. Plant Physiol 125:1788-1801

Gomez-Roldan V, Fermas S, Brewer PB et al (2008) Strigolactone inhibition of shoot branching. Nature 455:189-194

Gould PD, Locke JCW, Larue C et al (2006) The molecular basis of temperature compensation in the Arabidopsis circadian clock. Plant Cell 18:1177-1187

Graeber K, Nakabayashi K, Miatton E, Leubner-Metzger G, Soppe WJJ (2012) Molecular mechanisms of seed dormancy. Plant Cell Environ 35:1769-1786

Greb T, Clarenz O, Schäfer E, Muller D, Herrero R, Schmitz G, Theres K (2003) Molecular analysis of the LATERAL SUPPRESSOR gene in Arabidopsis reveals a conserved control mechanism for axillary meristem formation. Gene Dev 17:1175-1187

Groover AT (2005) What genes make a tree a tree? Trends Plant Sci 10:210-214

Groover AT, Mansfield SD, DiFazio SP, Dupper G, Fontana JR, Millar R, Wang Y (2006) The Populus homeobox gene ARBORKNOX 1 reveals overlapping mechanisms regulating the shoot apical meristem and the vascular cambium. Plant Mol Biol 61:917-932

Hackett WP (1985) Juvenility, maturation and re juvenility in woody plants. Hortic Rev 7:109-155

Halaly T, Pang X, Batikoff T, Crane O, Keren A, Venkateswari J, Ogrodovitch A, Sadka A, Lavee S, Or E (2008) Similar mechanisms might be triggered by alternative external stimuli that induce dormancy release in grape buds. Planta 228:79-88

Han KM, Dharmawardhana P, Arias RS, Ma C, Busov V, Strauss SH (2011) Gibberellin-associated cisgenesis modify growth, stature and wood properties in Populus. Plant Biotech J 9:162-178

Hanzawa Y, Takahashi T, Michael AJ, Burtin D, Long D, Pineiro M, Coupland G, Komeda Y (2000) ACAULIS 5, an Arabidopsis gene required for stem elongation, encodes a spermine synthase. EMBO J 19(16):4248-4256

Hareven D, Gutfinger T, Parnis A, Eshed Y, Lifschitz E (1996) The making of a compound leaf: genetic manipulation of leaf architecture in tomato. Cell 84:735-744

Hartig K, Beck E (2006) Crosstalk between auxin, cytokinin, and sugars in the plant cell cycle. Plant Biol 8:389-396

Hattori Y, Nagai K, Furukawa S et al (2009) The ethylene response factors SNORKEL 1 and SNORKEL 2 allow rice to adapt to deep water. Nature 460:1026-1030
Hay A, Tsiantis M (2010) KNOX genes: versatile regulators of plant development and diversity. Development 137:3153-3165

Hegedüs A (2006) Review of the Self-Incompatibility in Apple (Malus $\times$ domestica Borkh., syn.: Malus pumila Mill.). J Hortic Sci 12:31-36

Heide OM (1974) Growth and dormancy in Norway spruce ecotypes (Picea abies) I. Interaction of photoperiod and temperature. Physiol Plantarum 30:1-12

Heide OM (1993) Day length and thermal time responses of bud burst during dormancy release in some northern deciduous trees. Physiol Plantarum 88:531-540

Heide OM (2008) Interaction of photoperiod and temperature in the control of growth and dormancy of Prunus species. Sci Hortic 115:309-314

Heide OM, Prestrud AK (2005) Low temperature, but not photoperiod, controls growth cessation and dormancy induction and release in apple and pear. Tree Physiol 25:109-114

Hemmat M, Weeden NF, Conner PJ, Brown SK (1997) A DNA marker for columnar growth habit in apple contains a simple sequence repeat. J Am Soc Hortic Sci 122:347-349

Hibara K, Takada S, Tasaka M (2003) CUC 1 gene activates the expression of SAM-related genes to induce adventitious shoot formation. Plant J 36:687-696

Hirakawa Y, Kondo Y, Fukuda H (2010) TDIF peptide signaling regulates vascular stem cell proliferation via the WOX4 homeobox gene in Arabidopsis. Plant Cell 22:2618-2629

Hoad GV (1984) Hormonal regulation of fruit-bud formation in fruit trees. Acta Hort 149:13-24

Hsu CY, Liu Y, Luthe DS, Yuceer C (2006) Poplar FT2 shortens the juvenile phase and promotes seasonal flowering. Plant Cell 18:1846-1861

Hsu CY, Adams JP, Kim $\mathrm{H}$ et al (2011) FLOWERING LOCUS T duplication coordinates reproductive and vegetative growth in perennial poplar. PNAS 108(26):10756-10761

Huijser P, Schmid M (2011) The control of developmental phase transitions in plants. Development 138:4117-4129

Ikase L, Dumbravs R (2004) Breeding of columnar apple trees in Latvia. Biologija 2:8-10

Irish VF, Sussex IM (1990) Function of the apetala-1 gene during Arabidopsis floral development. Plant Cell 2:741-753

Israelsson M, Sundberg B, Moritz T (2005) Tissue-specific localization of gibberellins and expression of gibberellin-biosynthetic and signaling genes in wood-forming tissue in aspen. Plant $\mathbf{J}$ 44:494-504

Jacob HB (2010) Breeding experiments of apple varieties with columnar growth and low chilling requirements. Acta Hort pp 159-164

Jaillon O, Aury JM, Noel B, The French-Italian Public Consortium for Grapevine Genome Characterization et al (2007) The grapevine genome sequence suggests ancestral hexaploidization in major angiosperm phyla. Nature 449(7161):463-467

Ji L, Wang J, Ye M, Li Y, Guo B, Chen Z, Li H, An X (2013) Identification and characterization of the Populus AREB/ABF subfamily. J Integr Plant Biol 55(2):177-186

Jiao Y, Wang Y, Xue D et al (2010) Regulation of OsSPL14 by OsmiR156 defines ideal plant architecture in rice. Nat Genet 42:541-544

Johnson X, Brcich T, Dun EA, Goussot M, Haurogné K, Beveridge CA, Rameau C (2006) Branching genes are conserved across species. Genes controlling a novel signal in pea are coregulated by other long-distance signals. Plant Physiol 142:1014-1026

Jones B, Gunnerås SA, Petersson SV, Tarkowski P, Graham N, May S, Dolozal K, Sandberg G, Ljung K (2010) Cytokinin regulation of auxin synthesis in Arabidopsis involves a homeostatic feedback loop regulated via auxin and cytokinin signal transduction. Plant Cell 22:2956-2969 
Junttila O (1976) Growth cessation and shoot tip abscission in Salix. Physiol Plantarum 38:278-286

Junttila O (2007) Regulation of annual shoot growth cycle in northern tree species. In: Taulavuori E, Taulavuori K (eds) Physiology of northern plants under changing environment. Research Signpost, Kerala, pp 177-210

Junttila O, Hänninen H (2012) The minimum temperature for budburst in Betula depends on the state of dormancy. Tree Physiol 32:337-345

Kardailsky I, Shukla VK, Ahn JH, Dagenais N, Christensen SK, Nguyen JT, Chory J, Harrison MJ, Weigel D (1999) Activation tagging of the floral inducer FT. Science 286:1962-1965

Karlberg A, Bakó L, Bhalerao RP (2011) Short day-mediated cessation of growth requires the downregulation of AINTEGUMENTALIKE1 transcription factor in hybrid Aspen. PLoS Genet 7:e1002361

Kelsey DF, Brown SK (1992) 'McIntosh Wijcik': a columnar mutation of 'McIntosh' apple proving useful in physiology and research. Fruit Var J 46:83-87

Kenis K, Keulemans J (2007) Study of tree architecture of apple (Malus $\times$ domestica Borkh.) by QTL analysis of growth traits. Mol Breed 19:193-208

Kenis K, Keulemans J, Davey MW (2008) Identification and stability of QTLs for fruit quality traits in apple. Tree Genet Genomes 4:647-661

Kerstetter RA, Bollman K, Taylor RA, Bomblies K, Poethig RS (2001) KANADI regulates organ polarity in Arabidopsis. Nature 411:706-709

Kim MY, Song KJ, Hwang JH, Shin YU, Lee HJ (2003) Development of RAPD and SCAR markers linked to the Co gene conferring columnar growth habit in apple (Malus pumila Mill.). J Hort Sci Biotech 78:512-517

Knox JP, Wareing PF (1984) Apical dominance in Phaseolus vulgaris L.: the possible roles of abscisic and indole-3-acetic acid. J Exp Bot 35:239-244

Ko JH, Prassinos C, Keathley D, Han KH (2011) Novel aspects of transcriptional regulation in the winter survival and maintenance mechanism of poplar. Tree Physiol 31:208-225

Kobayashi Y, Kaya H, Goto K, Iwabuchi M, Araki T (1999) A pair of related genes with antagonistic roles in mediating flowering signals. Science 286:1960-1962

Koornneef M, Veen JH (1980) Induction and analysis of gibberellin sensitive mutants in Arabidopsis thaliana (L.) Heynh. Theor Appl Genet 58:257-263

Koutinas N, Pepelyankov G, Lichev V (2010) Flower induction and flower bud development in apple and sweet cherry. Biotechnol and Biotechnol Eq. 24(1):1549-1558

Křeček P, Skůpa P, Libus J, Naramoto S, Tejos R, Friml J, Zažímalová E (2009) The PIN-FORMED (PIN) protein family of auxin transporters. Genome Biol 10:249

Krost C, Petersen R, Schmidt ER (2012) The transcriptomes of columnar and standard type apple trees (Malus $\times$ domestica): a comparative study. Gene 498(2):223-230

Krost C, Petersen R, Lokan S, Brauksiepe B, Braun P, Schmidt ER (2013) Evaluation of the hormonal state of columnar apple trees (Malus $\times$ domestica) based on high throughput gene expression studies. Plant Mol Biol 81(3):211-220

Lamb RS, Hill TA, Tan QKG, Irish VF (2002) Regulation of APETALA3 floral homeotic gene expression by meristem identity genes. Development 129:2079-2086

Lane WD, Looney NE (1982) A selective tissue culture medium for growth of compact (dwarf) mutants of apple. Theor Appl Genet 61:219-223

Lang GA (1987) Dormancy: a new terminology. J Hortic Sci $22: 817-820$
Lang GA, Early JD, Martin GC, Darnell RL (1987) Endo-, para- and ecodormancy: physiological terminology and classification for dormancy research. J Hortic Sci 22:371-377

Langridge J (1957) Effect of day-length and gibberellic acid on the flowering of Arabidopsis. Nature 180:36-37

Lapins KO (1969) Segregation of compact growth types in certain apple seedling progenies. Can J Plant Sci 49:765-768

Lapins KO (1974) Spur-type growth habit in 60 apple progenies. J Am Soc Hortic Sci 99:568-572

Lapins KO (1976) Inheritance of compact growth type in apple. J Am Soc Hortic Sci 101:133-135

Lapins KO, Watkins R (1973) Genetics of compact growth habit. Report of East Malling Research Station for 1972136

Larisch C, Dittrich M, Widhagen H, Lautner S, Fromm J, Polle A, Hedrich R, Rennenberg H, Müller T, Ache P (2012) Poplar wood rays are involved in seasonal remodeling of tree physiology. Plant Physiol 160:1515-1529

Laux T, Mayer KF, Berger J, Jürgens G (1996) The WUSCHEL gene is required for shoot and floral meristem integrity in Arabidopsis. Development 122:87-96

Lawson DM, Hemmat M, Weeden NF (1995) The use of molecular markers to analyze the inheritance of morphological and developmental traits in apple. J Am Soc Hortic Sci 120:532-537

Lee JM, Looney NE (1977) Abscisic acid levels and genetic compaction in apple seedlings. Can J Plant Sci 5:81-85

Lee JM, Looney NE (1978) Changes in abscisic acid and gibberellin levels in apple seeds during stratification and their relationship to genetic compactation. Can J Plant Sci 58:761-767

Leyser O (2005) The fall and rise of apical dominance. Curr Opin Genet Dev 15:468-471

Li C, Bangerth F (1999) Autoinhibition of indoleacetic acid transport in the shoots of two-branched pea (Pisum sativum) plants and its relationship to correlative dominance. Physiol Plantarum 106:415-420

Li X, Xu M, Korban SS (2002) DNA methylation profiles differ between field- and in vitro-grown leaves of apple. J Plant Physiol 159:1229-1234

Li C, Yin C, Liu S (2004) Different responses of two contrasting Populus davidiana populations to exogenous abscisic acid application. Environ Exp Bot 51:237-246

Li P, Wang Y, Qian Q, Fu Z, Wang M, Zeng D, Li B, Wang X, Li J (2007) LAZY1 controls rice shoot gravitropism through regulating polar auxin transport. Cell Res 17:402-410

Li J, Sima W, Ouyang B et al (2012) Tomato SIDREB gene restricts leaf expansion and internode elongation by downregulating key genes for gibberellin biosynthesis. J Exp Bot 63(18): $6407-6420$

Liebhard R, Gianfranceschi L, Koller B, Ryder CD, Tarchini R, Van De Weg E, Gessler C (2002) Development and characterisation of 140 new microsatellites in apple (Malus $\times$ domestica Borkh.). Mol Breed 10:217-241

Liebhard R, Kellerhals M, Pfammatter W, Jertmini M, Gessler C (2003) Mapping quantitative physiological traits in apple (Malus $\times$ domestica Borkh.). Plant Mol Biol 52:511-526

Liu A, Eaton GW (1970) Comparative leaf anatomy of two standard and two compact apple mutants. Can J Plant Sci 50:733-735

Long JA, Moan EI, Medford JI, Barton MK (1996) A member of the KNOTTED class of homeodomain proteins encoded by the STM gene of Arabidopsis. Nature 379:66-69

Looney NE, Lane WD (1984) Spur-type growth mutants of McIntosh apple: a review of their genetics, physiology and field performance. Acta Hort 146:31-46

Majer C, Hochholdinger F (2011) Defining the boundaries: structure and function of LOB domain proteins. Trends Plant Sci $16: 47-52$ 
Maliepaard C, Alston FH, Van Arkel G et al (1998) Aligning male and female linkage maps of apple (Malus pumila Mill.) using multi-allelic markers. Theor Appl Genet 97:60-73

Mathan DS, Jenkins JA (1962) A morphogenetic study of lanceolate, a leaf-shape mutant in the tomato. Am J Bot 49:504-514

Matsumoto-Kitano M, Kusumoto T, Tarkowski P, Kinoshita-Tsujimura K, Václavíková K, Kakimoto T (2008) Cytokinins are central regulators of cambial activity. PNAS 105:20027-20031

Mauriat M, Moritz T (2009) Analyses of GA20ox- and GID1-overexpressing aspen suggest that gibberellins play two distinct roles in wood formation. Plant J 58:989-1003

Mayer KF, Schoof H, Haecker A, Lenhard M, Jürgens G, Laux T (1998) Role of WUSCHEL in regulating stem cell fate in the Arabidopsis shoot meristem. Cell 95:805-815

McConnell JR, Emery J, Eshed Y, Bao N, Bowman J, Barton MK (2001) Role of PHABULOSA and PHAVOLUTA in determining radial patterning in shoots. Nature 411:709-713

McKay M, Ross JJ, Lawrence NL, Cramp RE, Beveridge CA, Reid JB (1994) Control of internode length in Pisum sativum. Plant Physiol 106:1521-1526

Meulenbroek J, Verhaegh J, Janse J (1998) Inheritance studies with columnar type trees. Acta Hort 484:255-258

Milborrow BV (1967) The identification of (+)-Abscisin II $[(+)$-dormin] in plants and measurement of its concentrations. Planta 76:93-113

Mimida N, Kotoda N, Ueda T, Igarashi M, Hatsuyama Y, Iwanami H, Moriya S, Abe K (2009) Four TFL1/CEN-like genes on distinct linkage groups show different expression patterns to regulate vegetative and reproductive development in apple (Malus $\times$ domestica Borkh.). Plant Cell Physiolog 50(2):394-412

Mohamed R, Wang CT, Ma C et al (2010) Populus CEN/TFL1 regulates first onset of flowering, axillary meristem identity and dormancy release in Populus. Plant J 62:674-688

Moriya S, Iwanami H, Kotoda N, Takahashi S, Yamamoto T, Abe K (2009) Development of a marker-assisted selection system for columnar growth habit in apple breeding. J Jpn Soc Hort Sci 78:279-287

Moriya S, Okada K, Haji T, Yamamoto T, Abe K (2012) Fine mapping of $\mathrm{Co}$, a gene controlling columnar growth habit located on apple (Malus $\times$ domestica Borkh.) Linkage group 10 . Plant Breeding. doi: 10.1111/j.1439-0523.2012.01985.x

Müller D, Leyser O (2011) Auxin, cytokinin and the control of shoot branching. Ann Bot 107:1203-1212

Murray MB, Cannell MGR, Smith RI (1989) Date of bud burst of fifteen tree species in Britain following climatic warming. J Appl Ecol 26:693-700

Müssig C (2005) Brassinosteroid-promoted growth. Plant Biol 7:110-117

Newcomb RD, Crowhurst RN, Gleave AP et al (2006) Analyses of expressed sequence tags from apple. Plant Physiol 141:147-166

Nieminen K, Immanen J, Laxell M et al (2008) Cytokinin signaling regulates cambial development in poplar. PNAS 105:20032-20037

Nilsson J, Karlberg A, Antti H, Lopez-Vernaza M, Mellerowicz E, Perrot-Rechenmann C, Sandberg G, Bhalerao RP (2008) Dissecting the molecular basis of the regulation of wood formation by auxin in hybrid aspen. Plant Cell 20:843-855

Nordström A, Tarkowski P, Tarkowska D, Norbaek R, Âstot C, Dolezal K, Sandberg G (2004) Auxin regulation of cytokinin biosynthesis in Arabidopsis thaliana: a factor of potential importance for auxin-cytokinin-regulated development. PNAS 101:8039-8044

Ophir R, Pang X, Halaly T, Venkateswari J, Lavee S, Galbraith D, Or E (2009) Gene-expression profiling of grape bud response to two alternative dormancy-release stimuli expose possible links between impaired mitochondrial activity, hypoxia, ethyleneABA interplay and cell enlargement. Plant Mol Biol 71:402-423

Otsuga D, DeGuzman B, Prigge MJ, Drews GN, Clark SE (2001) REVOLUTA regulates meristem initiation at lateral positions. Plant J 25:223-236

Otto D, Petersen R, Krost C, Brandl R, Brauksiepe B, Braun P, Schmidt ER (2013) Molecular characterization of the Co gene region in Malus $\times$ domestica. Acta Hort (In press)

Overvoorde P, Fukaki H, Beeckman T (2010) Auxin control of root development. Cold Spring Harb Perspect Biol 2(6):a001537

Palme K, Gälweiler L (1999) PIN-pointing the molecular basis of auxin transport. Curr Opin Plant Biol 2:375-381

Park S, Keathley DE, Han KH (2008) Transcriptional profiles of the annual growth cycle in Populus deltoides. Tree Physiol 28:321-329

Peng J, Harberd NP (1997) Gibberellin deficiency and response mutations suppress the stem elongation phenotype of phytochrome-deficient mutants of Arabidopsis. Plant Physiol 113:1051-1058

Peng J, Richards DE, Hartley NM et al (1999) "Green revolution" genes encode mutant gibberellin response modulators. Nature 400:256-261

Péret B, Swarup K, Ferguson A et al (2012) AUX/LAX genes encode a family of auxin influx transporters that perform distinct functions during Arabidopsis development. Plant Cell 24:2874-2885

Phinney BO (1985) Gibberellin A1 dwarfism and shoot elongation in higher plants. Biol Plant 27:172-179

Popko J, Hänsch R, Mendel RR, Polle A, Teichmann T (2010) The role of abscisic acid and auxin in the response of poplar to abiotic stress. Plant Biol 12:242-258

Qi W, Sun F, Wang Q, Chen M, Huang Y, Feng YQ, Luo X, Yang J (2011) Rice ethylene-response AP2/ERF factor OsEATB restricts internode elongation by down-regulating a gibberellin biosynthetic gene. Plant Physiol 157:216-228

Quinlan JD, Tobutt KR (1990) Manipulating fruit tree structure chemically and genetically for improved performance. Hort Sci 25:60-64

Rameau C (2010) Strigolactones, a novel class of plant hormone controlling shoot branching. CR Biol 333:344-349

Randoux M, Jeauffre J, Thouroude T, Vasseur F, Hamama L, Juchaux M, Sakr S, Foucher F (2012) Gibberellins regulate the transcription of the continuous flowering regulator, $\operatorname{RoKSN}$, a rose TFL1 homologue. J Exp Bot 63(18):6543-6554

Reinhardt D, Kuhlemeier C (2001) Phyllotaxis in higher plants. In: McManus MT, Veit B (eds) Meristematic tissues in plant growth and development, 1st edn. Wiley, New York, pp 172-212

Reinhardt D, Mandel T, Kuhlemeier C (2000) Auxin regulates the initiation and radial position of plant lateral organs. Plant Cell 12:507-518

Rinne PLH, van der Schoot C (1998) Symplastic fields in the tunica of the shoot apical meristem coordinate morphogenic events. Development 125:1477-1485

Rinne PLH, Kaikuranta PM, van der Schoot C (2001) The shoot apical meristem restores its symplasmic organization during chilling-induced release from dormancy. Plant J 26:249-264

Rinne PLH, Welling A, Vahala J, Ripel L, Ruonala R, Kangasjärvi J, van der Schoot C (2011) Chilling of dormant buds hyperinduces FLOWERING LOCUS $\mathrm{T}$ and recruits GA-inducible 1,3- $\beta$ glucanases to reopen signal conduits and release dormancy in Populus. Plant Cell 23:130-146

Riou-Khamlichi C, Huntley R, Jacqmard A, Murray JAH (1999) Cytokinin activation of Arabidopsis cell division through a D-type cyclin. Science 283:1541-1544

Rohde A, Bhalerao RP (2007) Plant dormancy in the perennial context. Trends Plant Sci 12(5):217-222 
Running MP, Meyerowitz EM (1996) Mutations in the PERIANTHIA gene of Arabidopsis specifically alter floral organ number and initiation pattern. Development 122:1261-1269

Ruttink T, Arend M, Morreel K, Storme V, Rombauts S, Fromm J, Bhalerao RP, Boerjan W, Rohde A (2007) A molecular timetable for apical bud formation and dormancy induction in poplar. Plant Cell 19:2370-2390

Sachs T, Thimann KV (1967) The role of auxins and cytokinins in the release of buds from dominance. Am J Bot 54:136-144

Samach A, Onouchi H, Gold SE, Ditta GS, Schwarz-Sommer Z, Yanofsky MF, Coupland G (2000) Distinct roles of CONSTANS target genes in reproductive development of Arabidopsis. Science 288:1613-1616

Santamaria ME, Hasbun R, Valera MJ, Meijon M, Valledor L, Rodriguez JL, Toorop PE, Canal MJ, Rodriguez R (2009) Acetylated $\mathrm{H} 4$ histone and genomic DNA methylation patterns during bud set and bud burst in Castanea sativa. J Plant Physiol 166:1360-1369

Santamaria ME, Rodriguez R, Canal MJ, Toorop PE (2011) Transcriptome analysis of chestnut (Castanea sativa) tree buds suggests a putative role for epigenetic control of bud dormancy. Ann Bot Lond 108:485-498

Sarwar M, Skirvin RM (1997) Effect of thidiazuron and 6-Benzylaminopurine on adventitious shoot regeneration from leaves of three strains of "McIntosh" apple (Malus $\times$ domestica Borkh.) in vitro. Sci Hortic 68:95-100

Sarwar M, Skirvin RM, Kushad M, Norton MA (1998) Selecting dwarf apple (Malus $\times$ domestica Borkh.) Trees in vitro: multiple cytokinin tolerance expressed among three strains of "McIntosh" that differ in their growth habit under field conditions. Plant Cell Tiss Org 54:71-76

Schoof H, Lenhard M, Haecker A, Mayer KF, Jürgens G, Laux T (2000) The stem cell population of Arabidopsis shoot meristems is maintained by a regulatory loop between the CLAVATA and WUSCHEL genes. Cell 100:635-644

Schrader J, Nilsson J, Mellerowicz E, Berglund A, Nilsson P, Hertzberg M, Sandberg G (2004) A high-resolution transcript profile across the wood-forming meristem of poplar identifies potential regulators of cambial stem cell identity. Plant Cell 16:2278-2292

Schuster M (2009) Sour cherries Prunus cerasus L. with columnar tree habit. Acta Hort 814:325-328

Scorza R, Bassi D, Liverani A (2002) Genetic interactions of pillar (columnar), compact, and dwarf peach tree genotypes. J Am Soc Hortic Sci 127:254-261

Sehr EM, Agusti J, Lehner R, Farmer EE, Schwarz M, Greb T (2010) Analysis of secondary growth in the Arabidopsis shoot reveals a positive role of jasmonate signaling in cambium formation. Plant J 63(5):811-822

Seleznyova AN, Tustin DS, Thorp TG (2008) Apple dwarfing rootstocks and interstocks affect the type of growth units produced during the annual growth cycle: precocious transistion to flowering affects the composition and vigour of annual shoots. Ann Bot Lond 101:679-687

Shani E, Yanai O, Ori N (2006) The role of hormones in shoot apical meristem function. Curr Opin Plant Biol 9:484-489

Shannon S, Meeks-Wagner DR (1991) A mutation in the Arabidopsis TFL1 gene affects inflorescence meristem development. Plant Cell 3:877-892

Shimizu-sato S, Mori H (2001) Control of outgrowth and dormancy in axillary buds. Plant Physiol 127:1405-1413

Shulaev V, Sargent DJ, Crowhurst RN et al (2011) The genome of woodland strawberry (Fragaria vesca). Nat Genet 43:109-116

Siegfried KR, Eshed Y, Baum SF, Otsuga D, Drews GN, Bowman JL (1999) Members of the $Y A B B Y$ gene family specify abaxial cell fate in Arabidopsis. Development 126:4117-4128
Silfverberg-Dilworth E, Matasci CL, Van de Weg WE et al (2006) Microsatellite markers spanning the apple (Malus $\times$ domestica Borkh.) genome. Tree Genet Genomes 2:202-224

Snow R (1929) The transmission of inhibition through dead stretches of stem. Ann Bot 3:261-267

Snow M, Snow R (1942) The determination of axillary buds. New Phytol 41:13-22

Srikanth A, Schmid M (2011) Regulation of flowering time: all roads lead to Rome. Cell Mol Life Sci 68:2013-2037

Srinivasan C, Dardick C, Callahan A, Scorza R (2012) Plum (Prunus domestica) trees transformed with poplar FT1 result in altered architecture, dormancy requirement, and continuous flowering. PLoS One 7:e40715

Suarez-Lopez P, Wheatley K, Robson F, Onouchi H, Valverde F, Coupland G (2001) CONSTANS mediates between the circadian clock and the control of flowering in Arabidopsis. Nature 410:1116-1120

Sun TP, Kamiya Y (1994) The Arabidopsis GAl locus encodes the cyclase ent-kaurene synthetase A of gibberellin biosynthesis. Plant Cell 6:1509-1518

Sussex IM (1955) Morphogenesis in Solanum tuberosum L.: experimental investigation of leaf dorsoventrality and orientation in the juvenile shoot. Phytomorphology 5:286-300

Swarup R, Péret B (2012) AUX/LAX family of auxin influx carriers: an overview. Front Plant Sci 3:225

Swarup K, Benkovà E, Swarup R et al (2008) The auxin influx carrier LAX3 promotes lateral root emergence. Nat Cell Biol 10(8):946-954

Talon M, Koornneef M, Zeevaart JAD (1990) Endogenous gibberellins in Arabidopsis thaliana and possible steps blocked in the biosynthetic pathways of the semidwarf ga4 and ga5 mutants. PNAS 87:7983-7987

Thimann KV, Skoog F (1933) Studies on the growth hormone of plants. III. The inhibiting action of the growth substance on bud development. PNAS 19:714-716

Tian YK, Wang CH, Zhang JS, James C, Dai HY (2005) Mapping Co, a gene controlling the columnar phenotype of apple, with molecular markers. Euphytica 145:181-188

Tobutt KR (1985) Breeding columnar apple trees at east malling. Acta Hort 159:63-68

Tobutt KR (1988a) Columnar apple tree-maypole variety. US Plant Patent No 6, p 184

Tobutt KR (1988b) Columnar apple tree-telamon variety. US Plant Patent No 6, p 224

Tobutt KR (1988c) Columnar apple tree-tuscan variety. US Plant patent No 6, p 225

Tobutt KR (1988d) Columnar apple tree-trajan variety. US Plant patent No 6, p 226

Tobutt KR (1994) Combining apetalous parthenocarpy with columnar growth habit in apple. Euphytica 77:51-54

Todaka D, Nakashima K, Maruyama K et al (2012) Rice phytochrome-interacting factor-like protein OsPIL1 functions as a key regulator of internode elongation and induces a morphological response to drought stress. PNAS 109(39):15947-15952

Tsuge T, Tsukaya H, Uchimiya H (1996) Two independent and polarized processes of cell elongation regulate leaf blade expansion in Arabidopsis thaliana (L.) Heynh. Development 122:1589-1600

Tsukaya H (2005) Leaf shape: genetic controls and environmental factors. Int J Dev Biol 49:547-555

Tuskan GA, DiFazio S, Jansson S et al (2006) The genome of black cottonwood, Populus trichocarpa (Torr. \& Gray). Science 313(5793): 1596-1600

Uggla C, Moritz T, Sandberg G, Sundberg B (1996) Auxin as a positional signal in pattern formation in plants. PNAS 93:9282-9286 
Uggla C, Mellerowicz EJ, Sundberg B (1998) Indole-3-acetic acid controls cambial growth in scots pine by positional signaling. Plant Physiol 117:113-121

Umehara M, Hanada A, Yoshida S et al (2008) Inhibition of shoot branching by new terpenoid plant hormones. Nature 455:195-200

Valverde F, Mouradov A, Soppe W, Ravenscroft D, Samach A, Coupland G (2004) Photoreceptor regulation of CONSTANS protein in photoperiodic flowering. Science 303(5660):1003-1006

Veit B, Briggs SP, Schmidt RJ, Yanofsky MF, Hake S (1998) Regulation of leaf initiation by the terminal ear 1 gene of maize. Nature 393:166-168

Velasco R, Zharkikh A, Affourtit J et al (2010) The genome of the domesticated apple (Malus $\times$ domestica Borkh.). Nat Genet 42:833-839

Verde I, Abbott AG, Scalabrin S, The International Peach Genome Initiative et al (2013) The high-quality draft genome of peach (Prunus persica) identifies unique patterns of genetic diversity, domestication and genome evolution. Nat Genet 45(5):487-494

Wada M, Cao Q, Kotoda N, Soejima J, Masuda T (2002) Apple has two orthologues of FLORICAULA/LEAFY involved in flowering. Plant Mol Biol 49:567-577

Wang Y, Li J (2008) Molecular basis of plant architecture. Annu Rev Plant Biol 59:253-279

Wang JW, Park MY, Wang LJ, Koo Y, Chen XY, Weigel D, Poethig RS (2011) MiRNA control of vegetative phase change in trees. PLoS Genet 7:e1002012

Wang A, Aldwinckle H, Forsline P, Main D, Fazio G, Brown S, Xu K (2012) EST contig-based ssr linkage maps for Malus $\times$ domestica cv royal gala and an apple scab resistant accession of $M$. sieversii, the progenitor species of domestic apple. Mol Breed 29:379-397

Watanabe M, Suzuki A, Komori S, Bessho H (2004) Comparison of endogenous IAA and cytokinins in shoots of columnar and normal type apple trees. J Jpn Soc Hort Sci 73:19-24

Watanabe M, Suzuki A, Komori S, Bessho H (2006) Effects of heading-back pruning on shoot growth and IAA and cytokinin concentrations at bud burst of columnar-type apple trees. J Jpn Soc Hortic Sci 75:224-230

Watanabe M, Bessho H, Suzuki A, Komori S (2008) Seasonal changes of IAA and cytokinin in shoots of columnar type apple trees. Acta Hort 774:75-80

Weigel D, Alvarez J, Smyth DR, Yanofsky MF, Meyerowitz EM (1992) $L E A F Y$ controls floral meristem identity in Arabidopsis. Cell 69:843-859

Werner T, Motyka V, Laucou V, Smets R, Van Onckelen H, Schmülling T (2003) Cytokinin-deficient transgenic Arabidopsis plants show multiple developmental alterations indicating opposite functions of cytokinins in the regulation of shoot and root meristem activity. Plant Cell 15:2532-2550

Wigge PA, Kim MC, Jaeger KE, Busch W, Schmid M, Lohmann JU, Weigel D (2005) Integration of spatial and temporal information during floral induction in Arabidopsis. Science 309:1056-1059
Wilson BF (2000) Apical control of branch growth and angle in woody plants. Am J Bot 87(5):601-607

Wilson RN, Heckman JW, Somerville CR (1992) Gibberellin is required for flowering in Arabidopsis thaliana under short days. Plant Physiol 100:403-408

Wullschleger SD, Weston DJ, DiFazio SP, Tuskan GA (2013) Revisiting the sequencing of the first tree genome: Populus trichocarpa. Tree Physiol 33(4):357-364

$\mathrm{Xu}$ Y, Chang PFL, Liu D, Narasimhan ML, Raghothama KG, Hasegawa PM, Bressan RA (1994) Plant defense genes are synergistically induced by ethylene and methyl jasmonate. Plant Cell 6:1077-1085

Yamamuro C, Ihara Y, Wu X, Noguchi T, Fujioka S, Takatsuto S, Ashikari M, Kitano H, Matsuoka M (2000) Loss of function of a rice brassinosteroid insensitive1 homolog prevents internode elongation and bending of the lamina joint. Plant Cell 12:1591-1605

Yamane H, Ooka T, Jotatsu H, Hosaka Y, Sasaki R, Tao R (2011) Expressional regulation of PpDAM5 and PpSAM6, peach (Prunus persica) dormancy associated MADS-box genes, by low temperature and dormancy-breaking reagent treatment. J Exp Bot 62:3481-3488

Yoo SK, Chung KS, Kim J, Lee JH, Hong SM, Yoo SJ, Yoo SY, Lee JS, Ahn JH (2005) CONSTANS activates SUPPRESSOR OF OVEREXPRESSION OF CONSTANS 1 through FLOWERING LOCUS T to promote flowering in Arabidopsis. Plant Physiol 139:770-778

Yu B, Lin Z, Li H et al (2007) TAC1, a major quantitative trait locus controlling tiller angle in rice. Plant J 52:891-898

Zawaski C, Kadmiel M, Pickens J, Ma C, Strauss S, Busov V (2011) Repression of gibberellin biosynthesis or signaling produces striking alterations in poplar growth, morphology and flowering. Planta 234:1285-1298

Zhang Y, Dai HY (2011) Comparison of photosynthetic and morphological characteristics, and micro-structure of roots and shoots, between columnar apple and standard apple trees of hybrid seedlings. Phyton 80:119-125

Zhang Y, Turner JG (2008) Wound-induced endogenous jasmonates stunt plant growth by inhibiting mitosis. PLoS One 3(11):e3699

Zhang J, Elo A, Helariutta Y (2011) Arabidopsis as a model for wood formation. Curr Opin Biotech 22:293-299

Zhang Y, Zhu J, Dai H (2012) Characterization of transcriptional differences between columnar and standard apple trees using RNA-seq. Plant Mol Biol Rep. doi:10.1007/s11105-011-0396-0

Zhou HL, He SJ, Cao YR, Chen T, Du BX, Chu CC, Zhang JS, Chen SY (2006) OsGLU1, a putative membrane-bound endo-1,4- $\beta$-Dglucanase from rice, affects plant internode elongation. Plant Mol Biol 60:137-151

Zhu YD, Zhang W, Li GC, Wang T (2007) Evaluation of inter-simple repeat analysis for mapping the Co gene in apple (Malus pumila Mill.). J Hortic Sci Biotech 82:371-376 